\title{
Enzymatic synthesis of oligo-D-galactofuranosides and L-arabinofuranosides: from molecular dynamics to immunological assays $\dagger+$
}

\author{
Ilona Chlubnová, ${ }^{a, b, c}$ Dominik Filipp, ${ }^{d}$ Vojtech Spiwok, ${ }^{c}$ Hana Dvořáková, ${ }^{e}$ Richard Daniellou, ${ }^{* a, b}$ \\ Caroline Nugier-Chauvin, ${ }^{* a, b}$ Blanka Králová ${ }^{c}$ and Vincent Ferrières ${ }^{a, b}$
}

\author{
Received 23rd December 2009, Accepted 15th February 2010 \\ First published as an Advance Article on the web 11th March 2010 \\ DOI: $10.1039 / b 926988 f$
}

D-Galactofuranosyl-containing conjugates are ubiquitous in many pathogenic microorganisms, but completely absent from mammals. As they may constitute interesting pharmacophores, recent works have been dedicated to their preparation. Besides well-reported chemical procedures, enzymatic approaches are still limited, mainly due to the lack of the corresponding biocatalysts. Based on the similarity between chemical structures, the arabinofuranosyl hydrolase Araf 51 from Clostridium thermocellum was expected to recognize both the L-Ara $f$ motif and its D-Galf analogue. Molecular dynamics and STD-NMR were firstly used to confirm this hypothesis and increase our knowledge of the active site. Interestingly, this arabinofuranosidase was not only able to hydrolyze galactosyl derivatives, but was also really efficient in catalyzing oligomerisations using $p$-nitrophenyl furanosides as donors. The structures of the products obtained were determined using mass spectrometry and NMR. Amongst them, all the possible regioisomers of di-arabino and -galactofuranosides were synthesized, and the ratio of each regioisomer was easily tuned with respect to the reaction time. Especially, the galactofuranobioside displaying the biologically relevant sequence $\beta$-D-Gal $f$-(1,6)- $\beta$-D-Gal $f$ was enzymatically prepared for the first time. All fractions going from di- to penta-arabino- and galactofuranosides were tested for their ability in eliciting the production of TNF- $\alpha$. Interesting immunological properties were observed with arabinofuranosides as short as three sugar residues.

\section{Introduction}

D-Galactose is by far the most widespread hexose found in the furanose form in naturally occurring glycoconjugates from many bacteria, protozoa, fungi, plants and archaebacteria. ${ }^{1}$ One impressive example is that of Mycobacterium tuberculosis. Despite several decades of successful chemotherapeutic treatment, this microorganism has re-emerged through multidrug resistance to become a major cause of mortality, with an annual rate of approximately three million deaths over the world. The cell wall complex in this species is largely composed of two polysaccharides, a lipoarabinomannan (LAM) and an arabinogalactan (AG), in which all of the D-galactose and the D-arabinose residues are present as five-membered rings. ${ }^{2}$ The AG portion of mycobacteria comprises a linear chain of approximately 30 alternating

${ }^{a}$ Ecole Nationale Supérieure de Chimie de Rennes, CNRS, UMR 6226 Avenue du Général Leclerc, CS 50837, 35708 Rennes Cedex 7, France. E-mail: richard.daniellou@ensc-rennes.fr, caroline.nugier@ensc-rennes.fr, Fax: (+) 33-2-23-23-80-46; Tel: (+) 33-2-23-23-80-96

${ }^{b}$ Université européenne de Bretagne, France

'Department of Biochemistry and Microbiology, Institute of Chemical Technology of Prague, Techniká 3, 16628 Prague 6, Czech Republic

${ }^{d}$ Laboratory of Immunobiology, Institute of Molecular Genetics AS CR, Videnska 1083, 14220 Prague 4, Czech Republic

${ }^{e}$ Laboratory of NMR spectroscopy, Institute of Chemical Technology of Prague, Techniká 5, 16628 Prague 6, Czech Republic

$\dagger$ This paper is part of an Organic \& Biomolecular Chemistry web theme issue on biocatalysis.

\$ Electronic supplementary information (ESI) available: NMR spectra of compounds 3-13. See DOI: 10.1039/b926988f $\beta$ - $(1,5)$ - and $\beta$ - $(1,6)$-linked D-Galf residues. Moreover, the latter has been described to be essential for the growth and survival of mycobacteria. ${ }^{3}$ Both AG and LAM have critical roles in the pathogenicity of mycobacterial diseases, including tuberculosis. ${ }^{2,4}$ More precisely, inhibition of enzymes that assemble these polysaccharides prevents proliferation of mycobacteria. ${ }^{5}$ Noteworthily, these hexofuranosides are not present in mammals. Therefore, structurally well-defined synthetic analogues are of great interest for the development of new pharmacophores and new therapies. ${ }^{6-9}$ Some of them have been proven to present antigenic properties. For instance, $\beta$-D-Galf $O$-linked oligosaccharides, found in Penicillium and Aspergillus species, appeared to be immunodominant. ${ }^{10,11}$ Many efforts were then dedicated to the chemical synthesis of fragments of natural galactofuranose-containing glycosides. ${ }^{1,12}$ Disaccharidic sequences such as $\beta$-D-Gal $f-(1,5)-\beta$-D-Gal $f$ and $\beta$ D-Gal $f-(1,6)-\beta-\mathrm{D}-\mathrm{Gal} f,{ }^{13-18}$ as well as trisaccharidic units of the galactan produced by $M$. tuberculosi ${ }^{19}$ have been synthesized. However, the number of methods involving biocatalysts is still quite limited, probably due to the low availability of the required specific enzymes. Lowary and colleagues have recently studied a galactofuranosyl transferase and performed a small elongation of a galactofuranosyl chain. ${ }^{20}$ Nevertheless, and to the best of our knowledge, no galactofuranosyl hydrolase has been involved in chemo-enzymatic approaches. In this context, and owing to the structural similarity between residues of DGalf and L-Araf (Fig. 1), biocatalyzed furanosylation has been recently developed. The wild type arabinofuranosyl hydrolase Abf D3 (E.C.3.2.1.55) from Thermobacillus xylanolyticus was obviously efficient enough to recognize and transfer 4-nitrophenyl 


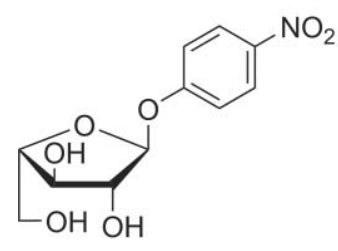

1

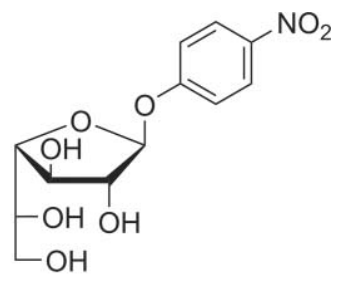

2
Fig. 1 Structural similarities between $p$ NP-L-Ara $f$ and $p$ NP-D-Gal $f 2$

L-arabinofuranoside 1 ( $p$ NP-Araf), but also the corresponding D-galactofuranoside 2 ( $p$ NP-Gal $f$ ) to either pyranosyl acceptors in transglycosylation reactions or to $p$ NP-Gal $f$ itself in autocondensation dimerizations. ${ }^{21,22}$ The versatility of this enzyme was further extended to the preparation of non-natural disaccharides obtained from 5-deoxy-L-arabinosyl and D-fucofuranosyl, as well as 6-fluoro-D-galactofuranosyl donors. ${ }^{23,24}$ Despite these interesting results towards the synthesis of $(1,2)$ - and $(1,3)$-difuranosides, further biocatalysts with quite different reactivity (regioselectivity, capability of oligomerization and/or branching) deserve to be studied and developed.

In this paper, we present our recent exploration of another $\alpha$-L-arabinofuranosyl hydrolase, Araf 51, from Clostridium thermocellum. ${ }^{25}$ This particular enzyme, belonging to the GH51 family, is known to remove $\alpha$-(1,2)-, $\alpha$-(1,3)- and $\alpha$-(1,5)-linked $\mathrm{L}$-arabinofuranosyl moieties from arabinans and xylans. We were thus really inclined to evaluate the potential synthetic ability of this enzyme for the preparation of both L-arabinofuranosyland D-galactofuranosyl-containing oligosaccharides. Molecular modelling was first performed to anticipate how the target pentose and hexose moieties fit within the active site of the enzyme. Subsequently, the scope of interactions evaluated in silico was completed in aqueous solution by a Saturation Transfer Difference NMR (STD-NMR) study. The Araf51-catalyzed oligomerizations using either $\mathbf{1}$ or $\mathbf{2}$ as favoured substrates were finally performed and the resulting oligofuranosides were examined as potent immunostimulating agents.

\section{Results and discussion}

Unlike $\mathrm{Ab} f \mathrm{D} 3$, the arabinofuranosidase Araf 51 has never been used for synthetic purposes up to now, and even $p$ NP-Galf 2 has never been reported to act as a substrate for this enzyme. However, since the amino acid sequences of these two biocatalysts share $26 \%$ of their identity, and since a similar active site has been revealed through X-ray determination of both crystal structures, ${ }^{25,26}$ we were likely to envisage Araf51 as a strong candidate for the enzymatic synthesis of oligogalactofuranosides.

\section{Molecular dynamics and STD-NMR}

Firstly, we compared the in silico behaviour of the natural ligand $\alpha$-L-arabinofuranosyl-(1,4)- $\alpha$-D-xylopyranoside (Ara $f$-Xyl $p$ ) to that of its Galf analogue ( $\mathrm{Gal} f-\mathrm{Xyl} p)$. Therefore, one subunit of the homohexameric enzyme containing the co-crystallized substrate was extracted from the $2 \mathrm{C} 8 \mathrm{~N}$ pdb file. The $6-\mathrm{C}$ side chain of one of the furanosyl parts was modified manually to obtain the analogue. Both complexes of enzyme and ligand were surrounded with explicit water in a periodic box, several molecules of water being changed for $\mathrm{Na}^{+}$in order to keep the box neutral. Finally, after optimization of the geometry, the simulations of molecular dynamics (MD) were first performed with fixed chosen atoms (restrained) for $0.2+0.2 \mathrm{~ns}$, in order to equilibrate each system, and then followed by a 5 ns unrestrained MD. Final pictures are depicted in Fig. 2. In both cases, the xylopyranoside derivative was rather flexible in the +1 subsite. Its major interaction with the protein seemed to occur through stacking with a tryptophan residue, thus confirming results previously obtained during the structural determination and explaining the substrate versatility naturally observed for such enzymes. Consequently, we inferred that the +1 subsite was likely to interact with a panel of aglycons, such as the furanosyl entity or aromatic rings. On the contrary, the Araf part of the natural ligand was quite stable during the simulation. This behaviour was mainly ascribed to a strong anchorage of the arabinosyl unit in the -1 subsite, due to the participation of multiple hydrogen bonds with at least six different amino acid residues. Interestingly, the Gal $f$ residue also stabilized in a similar position, thanks to an equivalent network of direct polar interactions, despite increased steric hindrance. Still, it is noteworthy that the hydroxymethyl group finally settled in a nonpolar cavity. Moreover, there was no indication that water binds to this cavity when an arabinoside substrate is in the active site of Araf 51. However, such computer modelling clearly demonstrated that the enzyme could be able to recognize the Galf motif, potentially even better than the Araf disaccharide. Therefore, this hypothesis encouraged us to pursue our study.

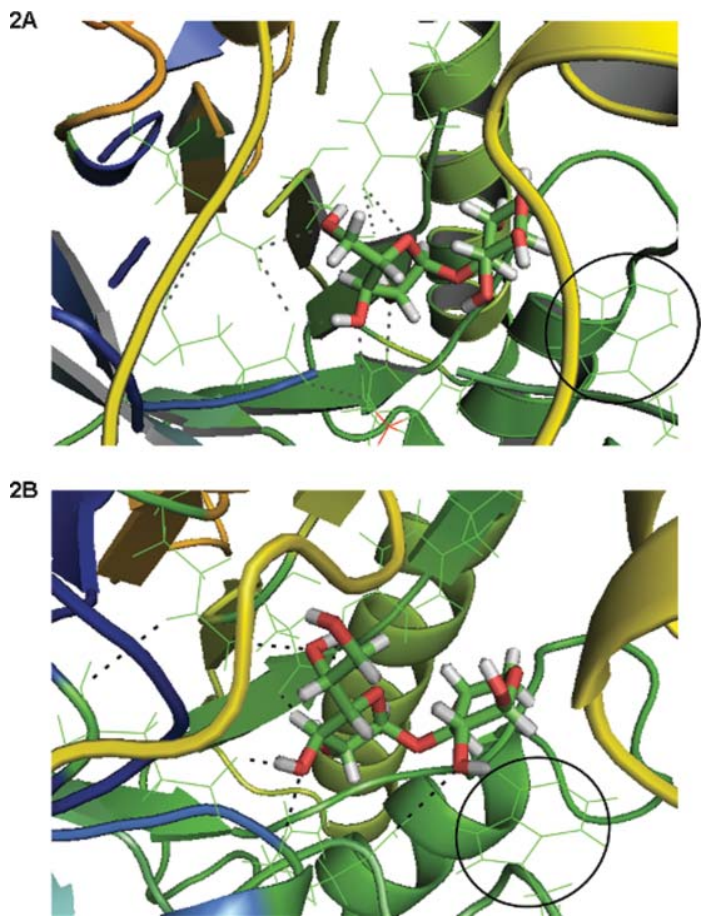

Fig. 2 Molecular modelling of arabinofuranoside (2A) and galactofuranoside (2B) in the active site or Araf 51 (the circle highlights the interesting tryptophan residue).

In order to complement our in silico findings, we also considered a physical method. Saturation Transfer Difference NMR (STD-NMR) nowadays constitutes a reliable and cheap tool for 
observing the interactions between ligand and protein. ${ }^{27}$ Particularly, this method allows the quantification of the relative importance of the interaction between each proton of a substrate and the active site. Because the previously used disaccharides were not commercially available, experiments were performed using both furanosides $\mathbf{1}$ and $\mathbf{2}$. To ensure observation of the STD effect, the E173A mutant ${ }^{25}$ was preferred to the wild type Araf51, in order to prevent hydrolysis of the substrates and, therefore, for simplifying NMR analysis. The resultant effects were expressed as percentages, giving $100 \%$ to be the highest signal, i.e. the proton in the meta position of the aromatic aglycon (Fig. 3). The $p$ NP rings in both $\mathbf{1}$ and $\mathbf{2}$ showed the strongest signals and, therefore, were in close contact with the active site of Araf 51, surely through a strong $\pi$-stacking interaction involving the tryptophan residue previously shown as responsible for the recognition of the xylopyranoside ring. Probably despite this particular effect caused by the artificial aglycon, the sugar ring displayed moderate signals. Nevertheless, all protons of the furanosyl moiety show STD effects. Particularly, 1 -H with its 12 or $11 \%$ effect for $\mathbf{1}$ and $\mathbf{2}$, respectively, appeared to have good interaction with residue(s) in the active site. Even more interestingly, the hindered 6-C side chain of $\mathbf{2}$ exhibited the same value as the hydroxymethyl group of $\mathbf{1}$ and did not disturb at all the way the sugar fit into the protein. Consequently, STD data complemented well in silico modelling and strengthened the thought that both molecules $\mathbf{1}$ and $\mathbf{2}$ exhibited a similar pattern of interactions with the arabinofuranosidase Araf 51, and could be engaged in biocatalytic reactions. However, these two studies needed to be complemented by the measurement of the specificity of the enzymes towards both substrates.
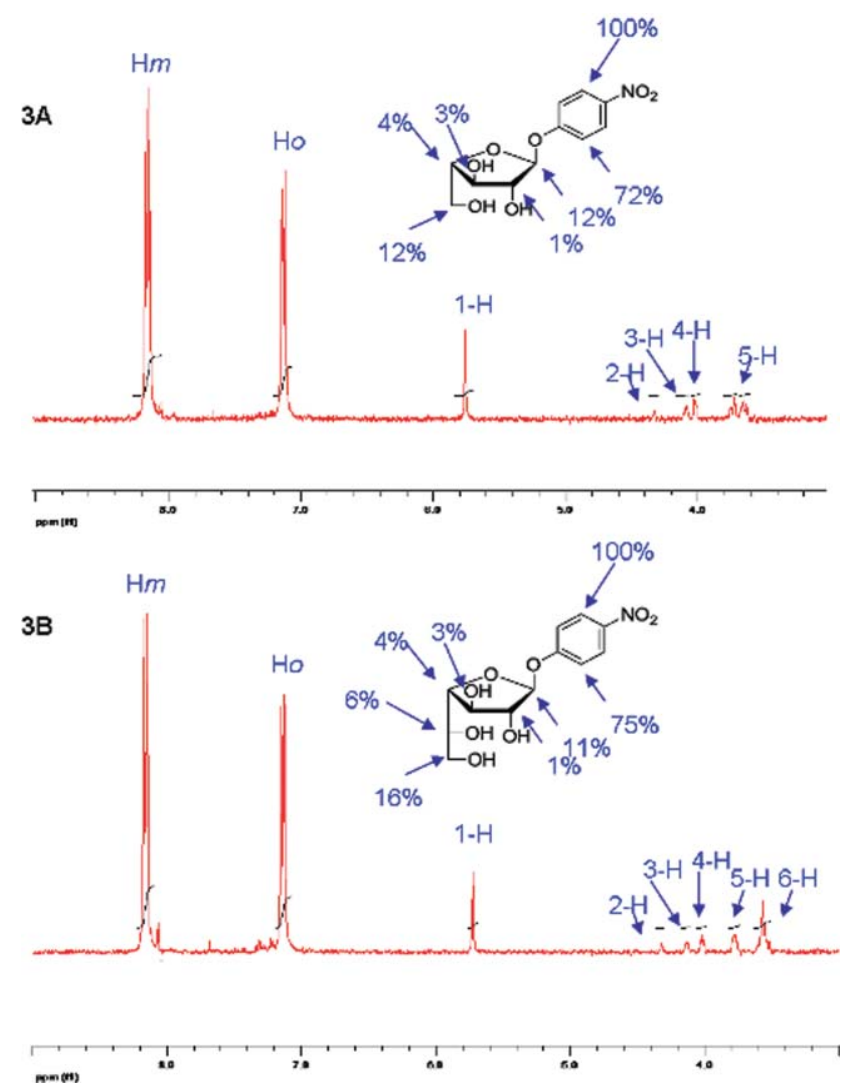

Fig. 3 STD-NMR spectra of $\mathbf{1}(3 \mathrm{~A})$ and 2 (3B).

\section{Kinetic parameters of Araf 51}

The kinetic parameters of Araf 51 were evaluated by looking at the hydrolytic activity of the enzyme towards the Gal $f$ derivative 2. Whereas Araf 51 is a thermophilic enzyme with $T_{\text {opt }} \sim 82{ }^{\circ} \mathrm{C}$, using $p$ NP-Araf 1 as a substrate, ${ }^{25}$ we determined its activity at $25^{\circ} \mathrm{C}$, for practical reasons. The value obtained for $K_{\mathrm{m}}$ for the hydrolysis of 1 under standard conditions (100 mM PBS pH 7, $1 \mathrm{mg} \mathrm{mL}^{-1} \mathrm{BSA}$ ) was $0.15 \mathrm{mM}\left(0.25 \mathrm{mM}\right.$ at $\left.37^{\circ} \mathrm{C}\right)$. Optimum $\mathrm{pH}$ was determined for this reaction using both 0.65 and $1 \mathrm{mM}$ as the substrate concentrations, and thus, appeared to be in the range of 7 to 8 . Evaluation of $K_{\mathrm{m}}$ for the hydrolysis of $\mathbf{2}$ under the same conditions showed a significantly greater value of $53 \mathrm{mM}$, similar to the one previously observed during $\mathrm{Ab} f \mathrm{D} 3$-catalyzed hydrolysis. ${ }^{23}$ Moreover, Araf 51-mediated hydrolysis of $\mathbf{2}$ was characterized by

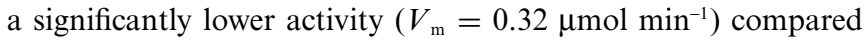

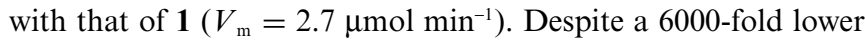
specificity $\left(V_{\mathrm{m}} / K_{\mathrm{m}}\right)$, the D-galactofuranoside $\mathbf{2}$ is still recognized as a substrate by the enzyme, as previously shown through the molecular modelling and the STD-NMR study. Nevertheless, measurement of the kinetic parameters clearly showed that Galf derivative $\mathbf{2}$ can be hydrolyzed, demonstrating that it is in a favourable position in the active site of Araf51, and might act as an efficient donor in auto-condensation reactions.

\section{Analytical study of the auto-condensation reactions}

Furanosides 1 and $2(5 \mathrm{mM})$ were incubated with Araf51 (2376 UI) at $60{ }^{\circ} \mathrm{C}$ and $\mathrm{pH}$ 7.4. Reactions were quenched by enzyme denaturation at $100{ }^{\circ} \mathrm{C}$ for three minutes before HPLC analysis. All products were separated thanks to size exclusion chromatography, and also detected and quantified by UV absorbance at $280 \mathrm{~nm}$. Newly observed peaks at shorter retention times than those corresponding to the substrates 1 (77.7 $\mathrm{min})$ and 2 (78.7 $\mathrm{min})$ were isolated. Mass spectrometric analyses allowed simple identification of four fractions, respectively containing penta- (10 $\mathrm{min})$, tetra- (13-15 min), tri- (18-20 min) and difuranosides (30$55 \mathrm{~min})$. In a second experiment, aliquots were withdrawn at increasing reaction times $(2,5,10,15$ and $20 \mathrm{~min})$ in order to evaluate the impact of time on the ratio of all synthesized oligofuranosides. Starting from arabinoside 1, the HPLC profile revealed that the substrate was completely consumed after less than $10 \mathrm{~min}$ (Fig. 4). Moreover, the overall conversion yield

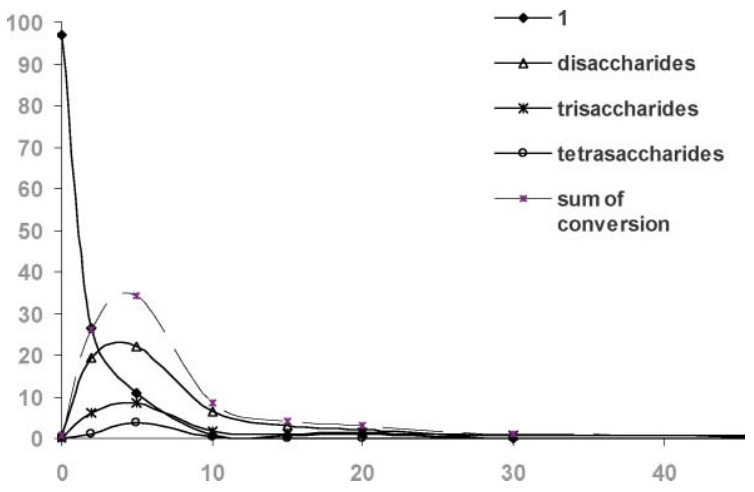

Fig. 4 Kinetics of the $p$ NP-Araf 1 auto-condensation products catalyzed by Araf 51 . The conversions were calculated as a percentage of the initial quantity of 1 from 0 to $45 \mathrm{~min}$. 
observed for the desired auto-condensation reaction reached its maximum at 35\% after approximately $5 \mathrm{~min}$. Interestingly, the di-, tri- and tetrasaccharides were produced right from the beginning of the Araf 51-catalyzed incubation with maximum conversions of $22.1,8.4$ and $3.6 \%$, respectively, within less than $5 \mathrm{~min}$ of reaction. Thereafter, decrease of the auto-condensation products were observed, suggesting the straightforward partial hydrolysis of these oligofuranosides.

As far as the $p$ NP-Galf 2 auto-condensation reaction was concerned, consumption of the substrate was nearly complete after 10 min (Fig. 5). Maximum conversion was indeed observed from 5 min and, thanks to mass spectrometric analysis, three fractions corresponding to di-, tri- and tetrasaccharides were identified, representing 34.6, 8.6 and $1.1 \%$ yield, respectively. Thereafter, the amount of disaccharide significantly decreased, while those of the upper tri- and tetrasaccharides still increased to reach a plateau at nearly 10 and $4 \%$, respectively. These analytical results clearly showed different behaviour between the arabinose and the galactose series towards Araf51. They could be ascribed (i) to a very interesting ability of the Araf 51 to recognize the galactofuranoside $\mathbf{2}$ and to use it as a donor in the glycosylation reaction, and (ii) to a lower capability of the biocatalyst for hydrolyzing the synthesized galactofuranosides, thus resulting in higher conversion yields starting from 2 .

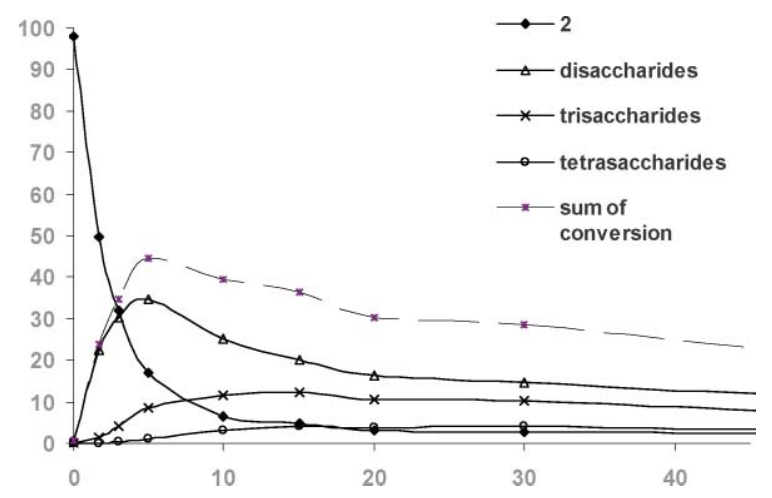

Fig. 5 Kinetics of the $p$ NP-Gal $f 2$ auto-condensation products catalyzed by Araf 51 . The conversion ratios were calculated as a percentage of the initial quantity of $\mathbf{2}$ from 0 to $45 \mathrm{~min}$.

\section{Preparative scale of enzymatic reaction}

Analytical results further needed to be sharpened in order to precisely elucidate the number of regioisomers formed, as well as the nature of the glycosidic linkages. When auto-condensation reactions were performed on larger scale $(100 \mathrm{mM}$ of substrate, i.e. $30 \mathrm{mg}$ of 1 or $100 \mathrm{mg}$ of 2) but with lower quantity of the biocatalyst, times had to be adjusted to 25 and $90 \mathrm{~min}$, respectively, in order to reach the maximum conversion. After denaturation of the enzyme at $100{ }^{\circ} \mathrm{C}$ for $10 \mathrm{~min}$, products were analyzed by usual TLC methods (see the ESI $\$$ ) and carefully separated thanks to the use of P2 biogel. Such size-exclusion chromatography allowed us to rapidly quantify the amounts of the different oligosaccharides, once again going from di- to pentafuranosides. Sugars with similar retention properties were then pooled together and finally lyophilized. Purified compounds were then identified using mass spectrometry and their structures were finally assessed through 1D and 2D NMR analysis.

Scale-up was first performed from the arabinoside 1. In accordance with the analytical studies, arabinofuranobiosides constituted the major fraction $(22.6 \%)$, followed by the trisaccharides $(7.9 \%)$ and the tetrasaccharides (3.1\%) (Table 1, entries 1-3). Moreover, even in low yield, we were also able to isolate pentasaccharides (entry 4), and prove their presence thanks to mass spectrometry. A more detailed analysis of the NMR data of the fraction containing the disaccharides permitted us to characterize the three different and possible regioisomers 3,4 and 5. Because the spectra were similar to those previously published, ${ }^{21}$ disaccharide 3, which was obtained with the best isolated yield of $12.6 \%$, was unambiguously identified as the $\alpha$-(1,2)-linked furanobioside. This result already constitutes a significant improvement on the enzymatic synthesis of this compound, as it was only isolated in $5.8 \%$ when using $\mathrm{Ab} f \mathrm{D} 3$. Subsequently, the small coupling constants observed between $1 \mathrm{~b}-\mathrm{H}$ and $2 \mathrm{~b}-\mathrm{H}\left(J_{1 \mathrm{~b}, 2 \mathrm{~b}}=1.8\right.$ and $1.2 \mathrm{~Hz}$ for $\mathbf{4}$ and $\mathbf{5}$, respectively) clearly indicated that the newly formed glycosidic bonds exhibited $\alpha$-L-stereochemistry. As 4 is concerned, its ${ }^{13} \mathrm{C}$ NMR spectra showed a downfield shift of the 3a-C $(\Delta \delta=+3.8 \mathrm{ppm}$, compared to $3 \mathrm{a}-\mathrm{C}$ of $\mathbf{1})$ of the reducing arabinofuranosyl moiety, as well as intense three-bond coupling in the ${ }^{1} \mathrm{H}-{ }^{13} \mathrm{C}(\mathrm{HMBC})$ spectra between $3 \mathrm{a}-\mathrm{C}(\delta=81.9 \mathrm{ppm})$ and $1 \mathrm{~b}-\mathrm{H}(\delta=5.06 \mathrm{ppm})$. This indicated that the linkage is $(1,3)$. For disaccharide 5, similar results were obtained, but involving $5 \mathrm{a}-\mathrm{C}(\Delta \delta=+4.0 \mathrm{ppm}$ compared to $1, \delta=66.6 \mathrm{ppm})$ and $1 \mathrm{~b}-$ $\mathrm{H}(\delta=4.92 \mathrm{ppm})$. These data demonstrated the presence of an $\alpha-\mathrm{L}-(1,5)$ bond between both furanosyl residues. Consequently, the three possible isomers could be synthesized thanks to the use of the Araf 51 biocatalyst. With structural data in hand, we also established the evolution profile according to reaction time (Fig. 6). Thus, between 2 and $10 \mathrm{~min}$, the ratio of $\mathbf{3 , 4}$ and 5 was significantly modified. Indeed, the $(1,2)$-linked disaccharide 3 was kinetically produced after $2 \mathrm{~min}$, but disappeared after $10 \mathrm{~min}$. On the other side, its $(1,5)$-linked counterpart was the major one after this time. As a consequence, and with regard to the observed regioselectivity of the reaction, as well as the amount obtained for each disaccharide, we can easily deduce that the $\alpha$-L- $(1,2)$ linkage is kinetically formed (but rapidly hydrolyzed thereafter), and that the $\alpha-\mathrm{L}-(1,5)$, and the $\alpha-\mathrm{L}-(1,3)$ but to a lesser extent, are thermodynamically favored. Such kinetic observations are in complete accordance with the hydrolytic preferences of Araf 51 towards arabinoxylane in nature, and emphasize the fact that frequently, information on the hydrolytic substrate specificity of glycosidases can be very valuable in order to predict the regioselectivity of transglycosylation reactions. ${ }^{28}$

Having elucidated the structures of disaccharides and their behaviour under the described conditions, we expected Araf51 to be able to produce all of the trisaccharidic regioisomers, but in various amounts. In this context, three different trifuranosides 6-8 were chromatographically separated and isolated in $2.7,0.6$ and $2.2 \%$ yield, respectively. On the assumption of small coupling constants between $1 \mathrm{~b}-\mathrm{H}$ and $2 \mathrm{~b}-\mathrm{H}\left(J_{1 \mathrm{~b}, 2 \mathrm{~b}}=1.2-1.8 \mathrm{~Hz}\right)$, and also between $1 \mathrm{c}-\mathrm{H}$ and $2 \mathrm{c}-\mathrm{H}\left(J_{\mathrm{cc}, 2 \mathrm{c}}=1.2 \mathrm{~Hz}\right), 1,2$-trans configurations between arabinosyl entities were easily established. The nature of the linkages was subsequently deduced from ${ }^{13} \mathrm{C}$ and ${ }^{1} \mathrm{H}-{ }^{13} \mathrm{C}$ NMR spectra. The arabinotrioside 6 was demonstrated to have two $(1,2)$ linkages, since the two carbon atoms exhibited signals 

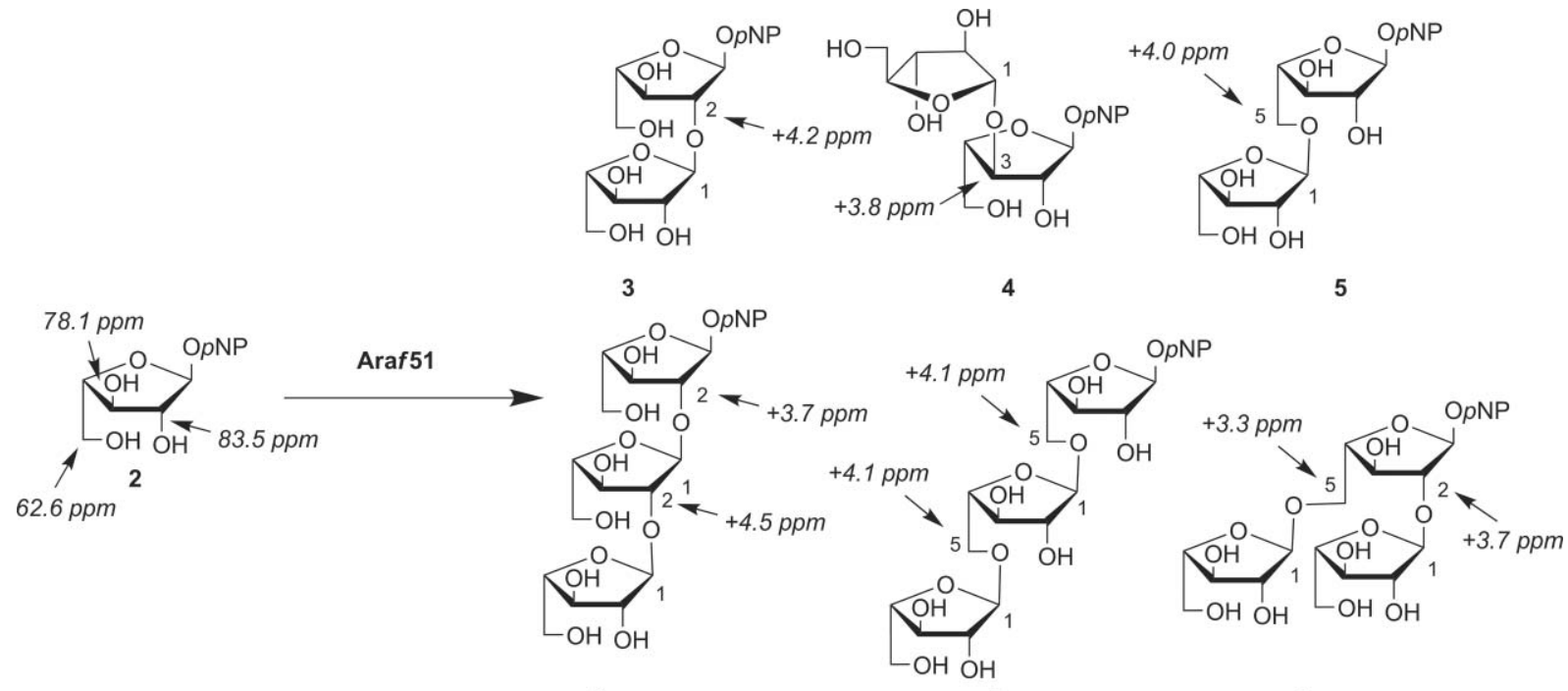

\begin{tabular}{llllr}
\hline Entry & Products & Yield $(\%)$ & Elucidated structures (yield, \%) \\
\hline 1 & Disaccharides & 22.6 & $\mathbf{3}(12.6)$ & $\mathbf{4}(2.2)$ \\
2 & Trisaccharides & 7.96 & $\mathbf{6}(2.7)$ & $\mathbf{7}(0.6)$ \\
3 & Tetrasaccharides & 3.1 & & $\mathbf{8}(2.1)$ \\
4 & Pentasaccharides & 0.1 & & \\
\hline
\end{tabular}

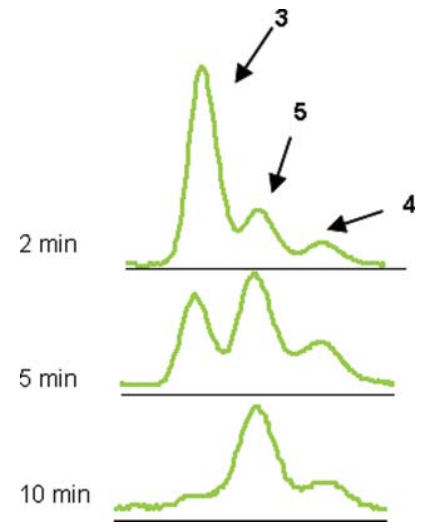

Fig. 6 HPLC profiles showing the modulation of the ratio of disaccharides $\mathbf{3}, \mathbf{4}$ and $\mathbf{5}$ in the presence of 2376 units of Araf 51.

with a downfield shift compared to 1 (for $2 \mathrm{a}-\mathrm{C}, \Delta \delta=+3.7 \mathrm{ppm}$, and for $2 \mathrm{~b}-\mathrm{C}, \Delta \delta=+4.5 \mathrm{ppm}$, Table 1). They also showed an intense correlation in the HMBC experiment with $1 \mathrm{~b}-\mathrm{H}(\delta=5.19$ $\mathrm{ppm})$ and $1 \mathrm{c}-\mathrm{H}(\delta=5.02 \mathrm{ppm})$, respectively. The structure of 7 was identified as the $(1,5)$ linear analogue as its $5 \mathrm{a}-\mathrm{C}$ and $5 \mathrm{~b}-\mathrm{C}$ showed upshifted signals $(\Delta \delta=+4.1 \mathrm{ppm})$, and correlations with 1b-H $(\delta=4.93 \mathrm{ppm})$ and $1 \mathrm{c}-\mathrm{H}(\delta=4.92 \mathrm{ppm})$. Finally, 8 was deduced to be the branched $(1,2)$ - and $(1,5)$-triarabinofuranoside using a similar reasoning, and the signals corresponding to $2 \mathrm{a}-\mathrm{C}$ $(\Delta \delta=+3.7 \mathrm{ppm})$ and $5 \mathrm{a}-\mathrm{C}(\Delta \delta=+3.3 \mathrm{ppm})$. Therefore, Araf51 showed very interesting versatility, even for the production of both linear and branched oligoarabinofuranosides.

Looking at the selectivity of Araf 51 during reactions involving $p$ NP-Araf 1 , we were really confident in isolating a great variety of oligogalactofuranosides starting from donor 2 (Table 2). As expected, disaccharides represented the major part of the isolated compounds, with a yield of $34.5 \%$, even higher than the one obtained in the arabinose series (entry 1). Tri- and tetrasaccharides were also obtained but in somewhat lower yields (entries 2 and 3 ). Only small amounts of derivatives with five sugar units were detected by mass spectrometry (entry 4). Unsurprisingly with regards to the structural similarity between L-Ara $f$ and D-Gal $f$, ${ }^{1} \mathrm{H}$ NMR spectra of all of the compounds showed signals for $1-\mathrm{H}$ with small $J_{1,2}$ coupling constants close to $1.2 \mathrm{~Hz}$, representative of a 1,2-trans $\beta$-D-glycodic linkages. Moreover, all of the possible regioisomers, i.e. $(1,2),(1,3),(1,5)$ and $(1,6)$, could be observed in the galactofuranobiosides fraction (entry 1). Notably, 9, which was previously enzymatically synthesized in an isolated yield of $6.0 \%$ using $\mathrm{Ab} f \mathrm{D} 3$, was obtained, herein, in $23.9 \%$ yield. ${ }^{22}$ All of the other structures were determined through careful analysis of the ${ }^{13} \mathrm{C}$ and the HMBC NMR spectra. Although the majority of these compounds were isolated in moderate quantities, the Araf 51-biocatalyzed reaction gave $\mathbf{1 2}$ in $7.8 \%$ yield. Moreover, it is important to note the influence of reaction time on the ratios of 9-12 (Fig. 7). Indeed, the (1,2)-linked digalactoside 9 was rapidly formed but also quickly disappeared from the reaction mixture. On the contrary, $(1,3),(1,5)$ and $(1,6)$ disaccharides were concomitantly obtained and their amounts remained constant under a large range of time. It is noteworthy that $\mathbf{1 2}$, the major thermodynamic disaccharide, displays the important sequence $\beta$ D-Gal $f-(1,6)-\beta-\mathrm{D}-\mathrm{Gal} f$. This is found in many pathogenic microorganisms, and was here enzymatically prepared for the first time. Finally, amongst the variety of possible oligogalactofuranosides, three trisaccharides were clearly characterized: (i) 13 presented a linear chain built up with $(1,2)$ glycosidic bonds, (ii) $\mathbf{1 4}$ exhibited 
Table 2 Auto-condensation of 2

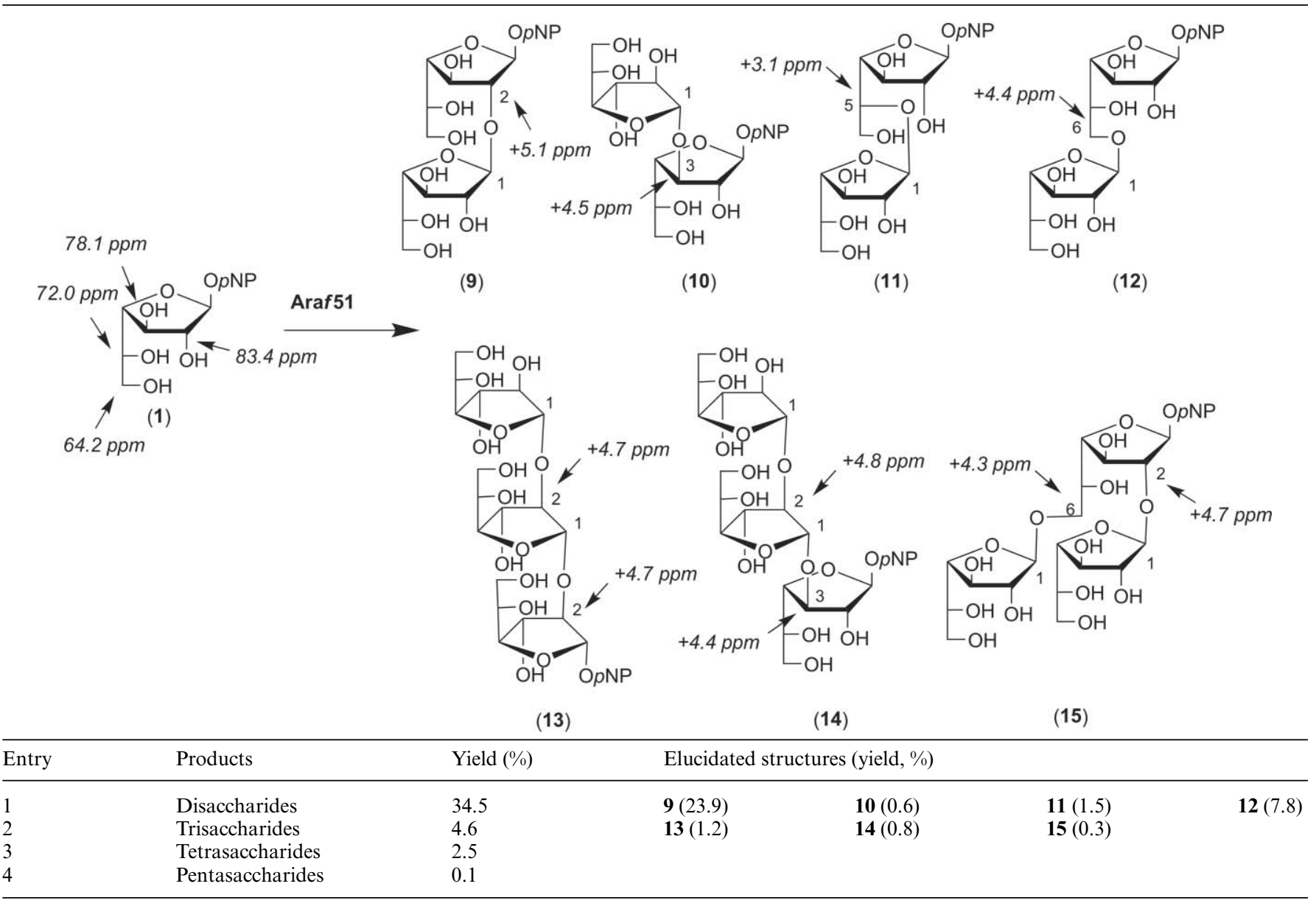

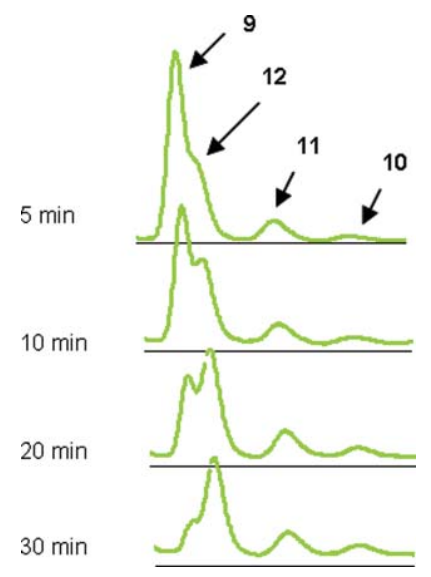

Fig. 7 HPLC profiles showing the modulation of ratio of disaccharides 9-12 in the presence of 2376 units of Araf 51.

$(1,2)$ and $(1,3)$ glycosidic linkages, and (iii) 15 , a branched $(1,2)$ and $(1,6)$ galactotrioside, resulted from the two favoured regiochemical preferences of Araf 51 .

\section{Biological evaluation}

The presence of galactofuranosyl residues in $M$. tuberculosis constitutes an interesting and original target in the fight against mycobacteria species. ${ }^{12}$ Therefore, the synthesis of small and welldefined oligofuranosides with immuno-modulatory properties represents a promising challenge. ${ }^{29,30}$ To assess the biological properties of the enzymatically synthesized neofuranosides described in this study, we incubated a murine macrophage cell line Raw 264 with either oligo-arabino or galactofuranosides. Their stimulatory effects measured by the TNF- $\alpha$ production were compared to those of a lipopolysaccharide (LPS) used as a positive control (Fig. 8). It is of note that trace levels of contaminating LPS in the samples used, measured by limulus assay, had no significant effect on the stimulatory activity of neofuranosides, as the addition of LPS inhibitor polymyxin B to cell cultures resulted in production of comparable levels of TNF- $\alpha$ (data not shown).

As depicted in Fig. 8 and in sharp contrast to LPS, none of the galactofuranosides were able to produce any significant response, even when used at concentrations up to $1 \mu \mathrm{g} \mathrm{mL}$. This observation may be assigned to both the short length of the oligosaccharide chains and to their high structural heterogeneity in the mixtures used. Importantly, significant $\mathrm{TNF}-\alpha$ responses were elicited upon stimulation with oligoarabinofuranosides when used at concentrations of $100 \mathrm{ng} \mathrm{mL} \mathrm{m}^{-1}$ and higher. Cytokine responses were concentration- and length of the oligosaccharidedependent (see columns Tri-, Tetra- and Penta-Ara). Stimulatory effects comparable to the Tri-Ara mixture were observed using isolated 6, 7 and $\mathbf{8}$. These data strongly suggest that the nature 


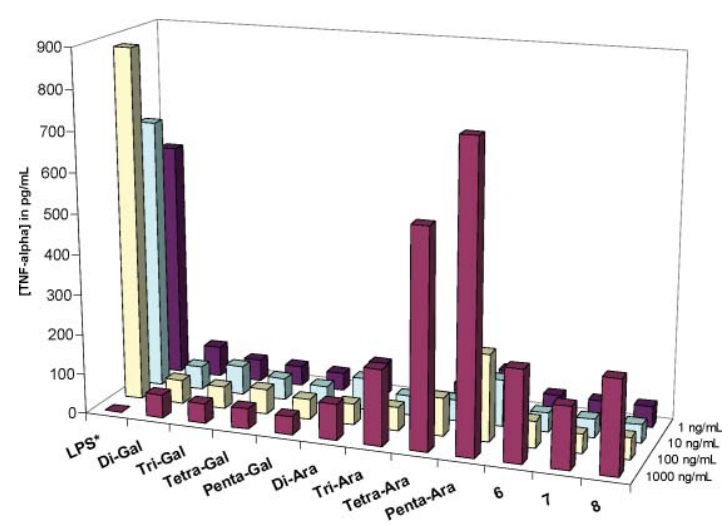

Fig. 8 Production of TNF- $\alpha$ cytokine upon macrophage stimulation with enzymatically synthesized oligoarabinofuranosides (Ara) and oligogalactofuranosides (Gal). (* Effect of LPS at $1000 \mathrm{ng} \mathrm{mL}^{-1}$ was not assessed.)

of the glycosidic linkages between furanosyl units, i.e. $(1,2),(1,3)$ and/or $(1,5)$, had no significant impact on the production of TNF$\alpha$. Thus, even if immune activities of polysaccharides containing furanosyl entities were already reported, ${ }^{31,32}$ this is the first time to the best of our knowledge that such short oligofuranosides, mimics of natural oligosaccharides derived from pathogens, are able to induce a cytokine response in immunocompetent cells.

\section{Conclusions}

Besides the $(1,2)$ and $(1,3)$ linkages already yielded by the arabinofuranosyl hydrolase $\mathrm{Ab} f \mathrm{D} 3$, the linkages $(1,5)$ and $(1,6)$, reported to be present in some clinically important pathogens, were obtained thanks to the assistance of Araf 51. These results also confirmed preferences of this easily available enzyme to transfer the furanosyl residue kinetically onto the 2-OH and thermodynamically to the primary hydroxyl function of the furanosyl acceptor, whatever the Araf or the Galf series. Moreover, the regioselectivity of the reaction was modulated with respect to reaction time. It also has to be pointed out that the isolated yields were significantly improved in all cases and thus, this enzymatic procedure is now at least as competitive as the corresponding multistep chemical reactions. Interestingly, Araf 51 appeared to be much more efficient as a synthetic tool than its counterpart $\mathrm{Ab} f \mathrm{D} 3$ : (i) the ratio of hydrolysis over auto-condensation of substrates as well as reaction times being reduced, (ii) autocondensation reactions being not limited to the preparation of disaccharides. These results encourage us to pursue the study of the synthetic potency of Araf51 and will lead us to the evaluation of its versatility towards original furanosyl-based substrates. Finally, immunostimulating responses obtained with short oligoarabinofuranosides are very promising, and this opens very interesting opportunities in this field, ${ }^{33}$ especially for further development on poly-L-arabinan directly extracted from biomass.

\section{Experimental}

\section{General procedures}

${ }^{1} \mathrm{H},{ }^{13} \mathrm{C}$, HSQC, HMBC and COSY NMR spectra were recorded on a Bruker 600 spectrometer equipped with a cryoprobe at
$600 \mathrm{MHz}$ for ${ }^{1} \mathrm{H}$ and $125 \mathrm{MHz}$ for ${ }^{13} \mathrm{C}$. Chemical shifts are given in $\delta$-units (ppm) measured downfield from $\mathrm{Me}_{4} \mathrm{Si}$. Coupling constants $J$ are given in Hz. Electrospray-ionisation mass spectra (ESI-MS) were recorded on samples dissolved in $\mathrm{MeOH}$ injected in a volume of $2-5 \mu \mathrm{L}$ into a flow $\left(100 \mu \mathrm{L} \mathrm{min}{ }^{-1}\right)$ of $\mathrm{MeOH}$ using a Q-TOF Micro (Waters, USA). Sample cone voltage was $42 \mathrm{~V}$ and the source temperature was $150{ }^{\circ} \mathrm{C}$. Measurements were performed in positive $\left([\mathrm{M}+\mathrm{Na}]^{+}\right.$ion detection $)$mode in the range of 100-1000 Da.

\section{Molecular dynamics}

All simulations were performed in GROMACS 3.3.2 package. ${ }^{34}$ A single subunit of arabinofuranosidase complexed with $\beta$-LAra $f-(1,3)-\beta-\mathrm{D}-\mathrm{Xyl} p$ (PDB ID: $2 \mathrm{C} 8 \mathrm{~N})$ was taken as the starting structure. ${ }^{25}$ The protein was modelled using the AMBER99SB force field. ${ }^{35}$ Protonation states of dissociable residues were assigned using the output from the $\mathrm{H}++$ tool. $^{36}$ Force field parameters of $\beta$-L-Ara $f-(1,3)-\beta$-D-Xyl $p$ were generated using Glycam server. ${ }^{37}$ Force field parameters of $\beta$-D-Gal $f-(1,3)-\beta$-D$\mathrm{Xyl} p$ were generated from those of $\beta$-L-Araf $f(1,3)-\beta-\mathrm{D}-\mathrm{Xyl} p$ by prolonging the hydroxymethyl moiety (missing parameters were taken from $N$-acetylneuraminic acid). Partial charges were taken from $\beta$-D-Gal $f$-OMe calculated using the RESP ${ }^{38}$ method at the HF/6-31G* level of theory using Gaussian03 package. ${ }^{39}$ Glycam topologies were then converted to GROMACS format using a modified amb2gmx.pl script (it was necessary to modify the script because in the original it ignores periodic functions in dihedral terms if they are multiplied by negative coefficients). ${ }^{40}$ The starting structure of the complex with $\beta$-L-Ara $f$-(1,3)- $\beta$-D-Xyl $p$ was taken from the crystal structure. An additional moiety of the complex with $\beta$-D-Gal $f-(1,3)-\beta$-D-Xyl $p$ was fitted manually. Structures were solvated by 13069 TIP3P ${ }^{41}$ water molecules and seven sodium ions to neutralize its net charge. The system was energy minimized and then equilibrated by 400 ps molecular dynamics simulation with harmonic restraints applied to non-hydrogen atoms of the protein ( $200 \mathrm{ps}$ strong and $200 \mathrm{ps}$ weak restraints). Finally, a $5 \mathrm{~ns}$ unrestrained molecular dynamics simulation was performed.

\section{STD-NMR experiments}

Samples were prepared in $0.5 \mathrm{~mL}$ of $\mathrm{D}_{2} \mathrm{O}$ and contained $\sim 30 \mu \mathrm{mol}$ of $p$ NP-sugars. STD-NMR spectra were recorded on a Bruker Avance III $400 \mathrm{MHz}$ spectrometer. Processing of all data was performed on a PC with Bruker Topspin v2.0 software. After the determination of the optimal conditions, i.e. temperature, delay between pulse $\left(d_{20}\right)$ and molecular ratio (protein : ligand), STDNMR experiments were performed at $283 \mathrm{~K}$ as followed. The protein $(1: 100$ ratio) was saturated on resonance at $0.7 \mathrm{ppm}$ and off resonance at $40 \mathrm{ppm}$ with a cascade of 40 selective gaussianshaped pulses of $50 \mathrm{~ms}$ duration with a $100 \mu$ s delay between each pulse. The total duration of the saturation time was set to 2 s. A total of 256 scans/STD-NMR experiment was acquired. A WATERGATE sequence was used to suppress residual HOD signal. A spin lock filter with strength of $5 \mathrm{kHz}$ and duration of $10 \mathrm{~ms}$ was also applied to suppress the protein background. A similar experiment with no enzyme was used as a reference in order to verify the absence of STD effects in these experimental conditions. Intensities of all STD effects were calculated though 
integrals over the respective signals in ${ }^{1} \mathrm{H}$ NMR reference spectra. The largest STD effect in each spectrum was set to $100 \%$ and relative intensities were determined, as common for non-refined STD effects. Hence, sufficient comparisons of relative STD effects between sugars were possible, but absolute binding intensities could not be determined.

\section{Production of the enzyme and determination of its kinetic parameters}

Recombinant arabinofuranosidase Araf51 expressed from the plasmid-borne Araf 51 gene was produced and purified from Escherichia coli cells as described previously. ${ }^{25}$ The hydrolytic activity of Araf 51 was quantified by incubation of the enzyme with 1 or $2(5 \mathrm{mM})$ in $100 \mathrm{mM}$ potassium phosphate buffer $\mathrm{pH} 7.4$ at $60{ }^{\circ} \mathrm{C}$. Continuous release of $p$-nitrophenol was measured at $405 \mathrm{~nm}$ (Microplate Spectrophotometer PowerWave XS/XS2, BioTek) and data evaluated with Gen5 Data Analysis Software (BioTek). One unit of activity corresponds to the amount of enzyme releasing $1 \mu \mathrm{mol}$ of $p$-nitrophenol per minute. Initial rate conditions and suitable substrate concentrations $(0.03-3 \mathrm{mM}$ and 0.625-40 mM for 1 and 2, respectively) were used in order to determine the kinetic parameters $K_{\mathrm{m}}$ and $k_{\text {cat }}$.

\section{Analytical scale of auto-condensation reactions}

Reactions were performed in buffered conditions (100 mM potassium phosphate buffer, $\mathrm{pH} 7.4$ ) at $60^{\circ} \mathrm{C}$ with shaking (INC Orbital Mixing Chilling/Heating Plate, Torrey Pines Scientific) in the presence of $p$ NP-glycosides $(50 \mathrm{mM})$ and $2376 \mathrm{U}$ of enzyme. The total reaction volume was $360 \mu \mathrm{L}$. Aliquots $(20 \mu \mathrm{L})$ of the reaction mixture were withdrawn at different times and the reaction was quenched by enzyme denaturation at $100{ }^{\circ} \mathrm{C}$ for $3 \mathrm{~min}$. Samples were mixed with $50 \mu \mathrm{L}$ of deionized water, passed through an ultrafiltration membrane (VectaSpin Microtubes, MWCO $12 \mathrm{kDa}$, Whatman) at $20000 \times \mathrm{g}$ for $30 \mathrm{~min}$ (Mikro $22 \mathrm{R}$, Hettich) to remove protein, and applied in a volume of $25 \mu \mathrm{L}$ to a calcium carbohydrate HPLC column. The HPLC system was consisting of a solvent delivery system 600 LCD HPLC Pump (Waters), an UV/VIS 486 Tunable Absorbance Detector (Waters) and Differential Refractometer RIDK 101 (Laboratorní Př́stroje Praha), equipped with a column (Supelcogel Ca, $30 \mathrm{~cm} \times$ $7.8 \mathrm{~mm}$, Supelco) and an appropriate guard column (Supelcogel $\mathrm{Ca}$ and $\mathrm{C} 611,5 \mathrm{~cm} \times 4.6 \mathrm{~mm}$, Supelco) maintained at $80{ }^{\circ} \mathrm{C}$ during the analysis. Deionized and filtrated (0.22 $\mu \mathrm{m}$ PVDF membrane, Millipore) water was used as a mobile phase in isocratic mode with a constant flow rate of $0.5 \mathrm{~mL} \mathrm{~min}^{-1}$. The substrate, products of auto-condensation and $p$-nitrophenol were detected and quantified by UV absorbance at $280 \mathrm{~nm}$.

\section{Preparative scale reactions}

Experiments were performed in $100 \mathrm{mM}$ phosphate buffer, $\mathrm{pH} 7.4$ at $60{ }^{\circ} \mathrm{C}$ in the presence of $p \mathrm{NP}$-glycosides $(100 \mathrm{mM})$ with 1440 $\mathrm{U}$ of Araf 51 in a total reaction volume of $1.05 \mathrm{~mL}$ for reaction with 1, and with $4800 \mathrm{U}$ of enzyme in a total reaction volume of $3.5 \mathrm{~mL}$ in the case of $\mathbf{2}$. Reaction mixtures were monitored by TLC (Kieselgel $60 \mathrm{~F}_{254}$ (Merck), ethyl acetate-acetic acid-water, $7: 2: 2$ ) and visualized under UV light and by exposure to $2 \%$ orcinol in $20 \% \mathrm{H}_{2} \mathrm{SO}_{4}$-ethanol. Auto-condensation reactions were stopped after $25 \mathrm{~min}$ or $90 \mathrm{~min}$ in the case of $\mathbf{1}$ and $\mathbf{2}$, respectively, by enzyme denaturation at $100{ }^{\circ} \mathrm{C}$ for $10 \mathrm{~min}$. The reaction products were separated by gel permeation chromatography on P-2 BioGel (Bio-Rad) using an FPLC system consisting of a solvent delivery system Biologic F40 DuoFlow, Biologic QuadTec UV-Vis Detector and Biologic BioFrac Fraction Collector (all Bio-Rad). Deionized filtrated (0.22 $\mu \mathrm{m}$ PVDF membrane, Millipore) water was used as a mobile phase with a flow rate of $0.15 \mathrm{~mL} \mathrm{~min}{ }^{-1}$. Separation was monitored by UV absorbance at 280 and $405 \mathrm{~nm}$ by operating software Biologic DuoFlow. Collected fractions were lyophilized (FreeZone Freeze Dry System, Labconco) and submitted to structural analyses.

p-Nitrophenyl $\alpha$-L-arabinofuranosyl-(1,2)- $\alpha$-L-arabinofuranoside (3). ${ }^{1} \mathrm{H}$ NMR (600 MHz, $\left.\mathrm{D}_{2} \mathrm{O}\right): \delta=8.11\left(2 \mathrm{H}, \mathrm{d}, J=9.6, \mathrm{H}_{m}\right.$ $\left.\mathrm{C}_{6} \mathrm{H}_{4}\right), 7.08\left(2 \mathrm{H}, \mathrm{d}, J=9.6, \mathrm{H}_{o} \mathrm{C}_{6} \mathrm{H}_{4}\right), 5.81\left(1 \mathrm{H}, \mathrm{d}, J_{1 \mathrm{a}, 2 \mathrm{a}}=1.5\right.$, $1 \mathrm{a}-\mathrm{H}), 5.08\left(1 \mathrm{H}, \mathrm{d}, J_{1 \mathrm{~b}, 2 \mathrm{~b}}=1.5,1 \mathrm{~b}-\mathrm{H}\right), 4.30\left(1 \mathrm{H}, \mathrm{dd}, J_{2 \mathrm{a}, 3 \mathrm{a}}=4.0\right.$, $2 \mathrm{a}-\mathrm{H}), 4.09\left(1 \mathrm{H}, \mathrm{dd}, J_{3 \mathrm{a}, 4 \mathrm{a}}=6.2,3 \mathrm{a}-\mathrm{H}\right), 4.02\left(1 \mathrm{H}, \mathrm{ddd}, J_{4 \mathrm{a}, 5 \mathrm{a}}=\right.$ $\left.3.3, J_{4 \mathrm{a}, 5^{\prime} \mathrm{a}}=5.1,4 \mathrm{a}-\mathrm{H}\right), 4.00\left(1 \mathrm{H}, \mathrm{dd}, J_{2 \mathrm{~b}, 3 \mathrm{~b}}=3.3,2 \mathrm{~b}-\mathrm{H}\right), 3.87(1 \mathrm{H}$, $\left.\mathrm{ddd}, J_{4 \mathrm{~b}, 5 \mathrm{~b}}=3.3, J_{3 \mathrm{~b}, 4 \mathrm{~b}}=J_{4 \mathrm{~b}, 5^{\prime} \mathrm{b}}=6.2,4 \mathrm{~b}-\mathrm{H}\right), 3.79(1 \mathrm{H}, \mathrm{dd}, 3 \mathrm{~b}-\mathrm{H})$, $3.68\left(1 \mathrm{H}, \mathrm{dd}, J_{5 \mathrm{a}, 5^{\prime} \mathrm{a}}=12.8,5 \mathrm{a}-\mathrm{H}\right), 3.59\left(1 \mathrm{H}, \mathrm{dd}, 5^{\prime} \mathrm{a}-\mathrm{H}\right), 3.55(1 \mathrm{H}$, $\left.\mathrm{dd}, J_{5 \mathrm{~b}, 5^{\prime} \mathrm{b}}=12.8,5 \mathrm{~b}-\mathrm{H}\right), 3.30\left(1 \mathrm{H}, \mathrm{dd}, 5^{\prime} \mathrm{b}-\mathrm{H}\right) \mathrm{ppm} .{ }^{13} \mathrm{C} \mathrm{NMR}$ $\left(125 \mathrm{MHz}, \mathrm{D}_{2} \mathrm{O}\right): \delta=161.4\left(\mathrm{C}_{i p s o} \mathrm{C}_{6} \mathrm{H}_{4}\right), 142.3\left(\mathrm{C}_{p} \mathrm{C}_{6} \mathrm{H}_{4}\right), 126.1$ $\left(\mathrm{C}_{m} \mathrm{C}_{6} \mathrm{H}_{4}\right), 116.7\left(\mathrm{C}_{o} \mathrm{C}_{6} \mathrm{H}_{4}\right), 107.6(1 \mathrm{~b}-\mathrm{C}), 104.5$ (1a-C), 87.3 (2aC), 84.2 (4b-C, 4a-C), 81.3 (2b-C), 76.6 (3b-C), 74.5 (3a-C), 61.0 (5b-C), 60.4 (5a-C) ppm. MS (ESI): $m / z$ calcd for $\mathrm{C}_{16} \mathrm{H}_{21} \mathrm{NNaO}_{11}$ $[\mathrm{M}+\mathrm{Na}]^{+}$426.1012; found 426.0892 .

p-Nitrophenyl $\alpha$-L-arabinofuranosyl-(1,3)- $\alpha$-L-arabinofuranoside (4). ${ }^{1} \mathrm{H}$ NMR $\left(600 \mathrm{MHz}, \mathrm{D}_{2} \mathrm{O}\right): \delta=8.11\left(2 \mathrm{H}, \mathrm{d}, J=9.6, \mathrm{H}_{m}\right.$ $\left.\mathrm{C}_{6} \mathrm{H}_{4}\right), 7.08\left(2 \mathrm{H}, \mathrm{d}, J=9.6, \mathrm{H}_{o} \mathrm{C}_{6} \mathrm{H}_{4}\right), 5.73\left(1 \mathrm{H}, \mathrm{d}, J_{1 \mathrm{a}, 2 \mathrm{a}}=1.2,1 \mathrm{a}-\right.$ $\mathrm{H}), 5.06\left(1 \mathrm{H}, \mathrm{d}, J_{1 \mathrm{~b}, 2 \mathrm{~b}}=1.8,1 \mathrm{~b}-\mathrm{H}\right), 4.43\left(1 \mathrm{H}, \mathrm{dd}, J_{2 \mathrm{a}, 3 \mathrm{a}}=2.4,2 \mathrm{a}-\mathrm{H}\right)$, $4.13\left(1 \mathrm{H}, \mathrm{ddd}, J_{4 \mathrm{a}, 5 \mathrm{a}}=3.0, J_{4 \mathrm{a}, 5^{\prime} \mathrm{a}}=5.4,4 \mathrm{a}-\mathrm{H}\right), 4.03\left(1 \mathrm{H}, \mathrm{dd}, J_{3 \mathrm{a}, 4 \mathrm{a}}=\right.$ $5.4,3 \mathrm{a}-\mathrm{H}), 4.00\left(1 \mathrm{H}, \mathrm{dd}, J_{2 \mathrm{~b}, 3 \mathrm{~b}}=3.0,2 \mathrm{~b}-\mathrm{H}\right), 3.88\left(1 \mathrm{H}, \mathrm{ddd}, J_{4 \mathrm{~b}, 5 \mathrm{~b}}=\right.$ $\left.3.0, J_{3 \mathrm{~b}, 4 \mathrm{~b}}=J_{4 \mathrm{~b}, 5^{\prime} \mathrm{b}}=6.0,4 \mathrm{~b}-\mathrm{H}\right), 3.80(1 \mathrm{H}, \mathrm{dd}, 3 \mathrm{~b}-\mathrm{H}), 3.71(1 \mathrm{H}, \mathrm{dd}$, $\left.J_{5 \mathrm{a}, 5^{\prime} \mathrm{a}}=12.6,5 \mathrm{a}-\mathrm{H}\right), 3.67\left(1 \mathrm{H}, \mathrm{dd}, J_{5 \mathrm{~b}, 5^{\prime} \mathrm{b}}=12.0,5 \mathrm{~b}-\mathrm{H}\right), 3.63(1 \mathrm{H}$, dd, 5'a-H), 3.54 (1H, dd, 5'b-H) ppm. ${ }^{13} \mathrm{C}$ NMR (125 MHz, $\left.\mathrm{D}_{2} \mathrm{O}\right)$ : $\delta=161.1\left(\mathrm{C}_{i p s o} \mathrm{C}_{6} \mathrm{H}_{4}\right), 142.3\left(\mathrm{C}_{p} \mathrm{C}_{6} \mathrm{H}_{4}\right), 126.1\left(\mathrm{C}_{m} \mathrm{C}_{6} \mathrm{H}_{4}\right), 116.8$ $\left(\mathrm{C}_{o} \mathrm{C}_{6} \mathrm{H}_{4}\right), 107.2$ (1b-C), 105.6 (1a-C), 84.4 (4a-C), 84.0 (4b-C), 81.9 (3a-C), 81.2 (2b-C), 79.5 (2a-C), 76.6 (3b-C), 61.1 (5b-C), 60.8 (5a-C) ppm. MS (ESI): $m / z$ calcd for $\mathrm{C}_{16} \mathrm{H}_{21} \mathrm{NNaO}_{11}[\mathrm{M}+$ $\mathrm{Na}^{+}$426.1012; found 426.1002.

p-Nitrophenyl $\alpha$-L-arabinofuranosyl-(1,5)- $\alpha$-L-arabinofuranoside (5). ${ }^{1} \mathrm{H}$ NMR (600 MHz, $\left.\mathrm{D}_{2} \mathrm{O}\right): \delta=8.11\left(2 \mathrm{H}, \mathrm{d}, J=9.6, \mathrm{H}_{m}\right.$ $\left.\mathrm{C}_{6} \mathrm{H}_{4}\right), 7.07\left(2 \mathrm{H}, \mathrm{d}, J=9.6, \mathrm{H}_{o} \mathrm{C}_{6} \mathrm{H}_{4}\right), 5.71\left(1 \mathrm{H}, \mathrm{d}, J_{1 \mathrm{a}, 2 \mathrm{a}}=1.8,1 \mathrm{a}-\right.$ $\mathrm{H}), 4.92\left(1 \mathrm{H}, \mathrm{d}, J_{1 \mathrm{~b}, 2 \mathrm{~b}}=1.2,1 \mathrm{~b}-\mathrm{H}\right), 4.27\left(1 \mathrm{H}, \mathrm{dd}, J_{2 \mathrm{a}, 3 \mathrm{a}}=3.0,2 \mathrm{a}-\mathrm{H}\right)$, $4.13\left(1 \mathrm{H}, \mathrm{ddd}, J_{4 \mathrm{a}, 5 \mathrm{a}}=3.0, J_{4,5^{\prime} \mathrm{a}}=5.4,4 \mathrm{a}-\mathrm{H}\right), 4.00\left(1 \mathrm{H}, \mathrm{dd}, J_{3 \mathrm{a}, 4 \mathrm{a}}=\right.$ $5.4,3 \mathrm{a}-\mathrm{H}), 3.95\left(1 \mathrm{H}, \mathrm{dd}, J_{2 \mathrm{~b}, 3 \mathrm{~b}}=3.0,2 \mathrm{~b}-\mathrm{H}\right), 3.92\left(1 \mathrm{H}, \mathrm{ddd}, J_{4 \mathrm{~b}, 5 \mathrm{~b}}=\right.$ $\left.3.0, J_{3 \mathrm{~b}, 4 \mathrm{~b}}=J_{4 \mathrm{~b}, 5^{\prime} \mathrm{b}}=6.0,4 \mathrm{~b}-\mathrm{H}\right), 3.78(1 \mathrm{H}, \mathrm{dd}, 3 \mathrm{~b}-\mathrm{H}), 3.75(1 \mathrm{H}$, $\left.\mathrm{dd}, J_{5 \mathrm{a}, 5^{\prime} \mathrm{a}}=12.0,5 \mathrm{a}-\mathrm{H}\right), 3.65\left(2 \mathrm{H}, \mathrm{dd}, J_{5 \mathrm{~b}, 5^{\prime} \mathrm{b}}=12.0,5 \mathrm{~b}-\mathrm{H}, 5^{\prime} \mathrm{a}-\mathrm{H}\right)$, 3.54 (1H, dd, $\left.5^{\prime} \mathrm{b}-\mathrm{H}\right) \mathrm{ppm} .{ }^{13} \mathrm{C}$ NMR $\left(125 \mathrm{MHz}, \mathrm{D}_{2} \mathrm{O}\right): \delta=161.2$ $\left(\mathrm{C}_{i p s o} \mathrm{C}_{6} \mathrm{H}_{4}\right), 142.3\left(\mathrm{C}_{p} \mathrm{C}_{6} \mathrm{H}_{4}\right), 126.1\left(\mathrm{C}_{m} \mathrm{C}_{6} \mathrm{H}_{4}\right), 116.7\left(\mathrm{C}_{o} \mathrm{C}_{6} \mathrm{H}_{4}\right)$, 107.4 (1b-C), 105.4 (1a-C), 84.0 (4b-C), 83.7 (4a-C), 81.0 (2a-C), 80.9 (2b-C), 76.5 (3b-C, 3a-C), 66.6 (5a-C), 61.2 (5b-C) ppm. MS (ESI): $m / z$ calcd for $\mathrm{C}_{16} \mathrm{H}_{21} \mathrm{NNaO}_{11}[\mathrm{M}+\mathrm{Na}]^{+} 426.1012$; found 426.1663 .

p-Nitrophenyl $\alpha$-L-arabinofuranosyl-(1,2)- $\alpha$-L-arabinofuranosyl(1,2)- $\alpha$-L-arabinofuranoside (6). ${ }^{1} \mathrm{H}$ NMR $\left(600 \mathrm{MHz}, \mathrm{D}_{2} \mathrm{O}\right): \delta=$ $8.11\left(2 \mathrm{H}, \mathrm{d}, J=9.6, \mathrm{H}_{m} \mathrm{C}_{6} \mathrm{H}_{4}\right), 7.08\left(2 \mathrm{H}, \mathrm{d}, J=9.6, \mathrm{H}_{o} \mathrm{C}_{6} \mathrm{H}_{4}\right)$, 
$5.82\left(1 \mathrm{H}, \mathrm{d}, J_{1 \mathrm{a}, 2 \mathrm{a}}=1.8,1 \mathrm{a}-\mathrm{H}\right), 5.19\left(1 \mathrm{H}, \mathrm{d}, J_{1 \mathrm{~b}, 2 \mathrm{~b}}=1.2,1 \mathrm{~b}-\mathrm{H}\right), 5.02$ $\left(1 \mathrm{H}, \mathrm{d}, J_{1 \mathrm{c}, 2 \mathrm{c}}=1.8,1 \mathrm{c}-\mathrm{H}\right), 4.30\left(1 \mathrm{H}, \mathrm{dd}, J_{2 \mathrm{a}, 3 \mathrm{a}}=3.6,2 \mathrm{a}-\mathrm{H}\right), 4.12$ $\left(1 \mathrm{H}, \mathrm{dd}, J_{3 \mathrm{a}, 4 \mathrm{a}}=6.0,3 \mathrm{a}-\mathrm{H}\right), 4.03\left(1 \mathrm{H}, \mathrm{ddd}, J_{4 \mathrm{a}, 5 \mathrm{a}}=3.0, J_{4 \mathrm{a}, 5^{\prime} \mathrm{a}}=5.4\right.$, $4 \mathrm{a}-\mathrm{H}), 4.00\left(1 \mathrm{H}, \mathrm{dd}, J_{2 \mathrm{~b}, 3 \mathrm{~b}}=3.6,2 \mathrm{~b}-\mathrm{H}\right), 3.97\left(1 \mathrm{H}, \mathrm{dd}, J_{2 \mathrm{c}, 3 \mathrm{c}}=3.0\right.$, $2 \mathrm{c}-\mathrm{H}), 3.92(2 \mathrm{H}, \mathrm{m}, 3 \mathrm{~b}-\mathrm{H}, 4 \mathrm{c}-\mathrm{H}), 3.86\left(1 \mathrm{H}, \mathrm{ddd}, J_{3 \mathrm{~b}, 4 \mathrm{~b}}=3.6, J_{4 \mathrm{~b}, 5 \mathrm{~b}}=\right.$ $\left.3.0, J_{4 \mathrm{~b}, 5^{\prime} \mathrm{b}}=5.4,4 \mathrm{~b}-\mathrm{H}\right), 3.80\left(1 \mathrm{H}, \mathrm{dd}, J_{3 \mathrm{c}, 4 \mathrm{c}}=6.0,3 \mathrm{c}-\mathrm{H}\right), 3.68(2 \mathrm{H}$, m, 5a-H, 5c-H), 3.56 (3H, m, 5'a-H, 5b-H, 5'c-H), 3.47 (1H, dd, $\left.J_{5 \mathrm{~b}, 5^{\prime} \mathrm{b}}=12.0,5^{\prime} \mathrm{b}-\mathrm{H}\right) \mathrm{ppm} .{ }^{13} \mathrm{C} \mathrm{NMR}\left(125 \mathrm{MHz}, \mathrm{D}_{2} \mathrm{O}\right): \delta=161.3$ $\left(\mathrm{C}_{i p s o} \mathrm{C}_{6} \mathrm{H}_{4}\right), 142.3\left(\mathrm{C}_{p} \mathrm{C}_{6} \mathrm{H}_{4}\right), 126.1\left(\mathrm{C}_{m} \mathrm{C}_{6} \mathrm{H}_{4}\right), 116.7\left(\mathrm{C}_{o} \mathrm{C}_{6} \mathrm{H}_{4}\right)$, 107.7 (1c-C), 106.2 (1b-C), 104.5 (1a-C), 88.0 (2b-C), 87.2 (2a-C), 84.4 (4a-C), 84.2 (3b-C), 82.8 (4b-C), 81.2 (2c-C), 76.5 (3c-C), 75.0 (4c-C), 74.5 (3a-C), 66.8 (5c-C), 60.6 (5a-C, 5b-C) ppm. MS (ESI): $m / z$ calcd for $\mathrm{C}_{21} \mathrm{H}_{29} \mathrm{NNaO}_{15}[\mathrm{M}+\mathrm{Na}]^{+} 558.1435$; found 558.2307 .

p-Nitrophenyl $\alpha$-L-arabinofuranosyl-(1,5)- $\alpha$-L-arabinofuranosyl(1,5)- $\alpha$-L-arabinofuranoside (7). ${ }^{1} \mathrm{H} \mathrm{NMR}\left(600 \mathrm{MHz}, \mathrm{D}_{2} \mathrm{O}\right): \delta=$ $8.11\left(2 \mathrm{H}, \mathrm{d}, J=9.6, \mathrm{H}_{m} \mathrm{C}_{6} \mathrm{H}_{4}\right), 7.08\left(2 \mathrm{H}, \mathrm{d}, J=9.6, \mathrm{H}_{o} \mathrm{C}_{6} \mathrm{H}_{4}\right)$, $5.72\left(1 \mathrm{H}, \mathrm{d}, J_{1 \mathrm{a}, 2 \mathrm{a}}=1.2,1 \mathrm{a}-\mathrm{H}\right), 4.93\left(1 \mathrm{H}, \mathrm{d}, J_{1 \mathrm{~b}, 2 \mathrm{~b}}=1.2,1 \mathrm{~b}-\mathrm{H}\right), 4.92$ $\left(1 \mathrm{H}, \mathrm{d}, J_{1 \mathrm{c}, 2 \mathrm{c}}=1.2,1 \mathrm{c}-\mathrm{H}\right), 4.27\left(1 \mathrm{H}, \mathrm{dd}, J_{2 \mathrm{a}, 3 \mathrm{a}}=3.0,2 \mathrm{a}-\mathrm{H}\right), 4.13$ $\left(1 \mathrm{H}, \mathrm{ddd}, J_{4 \mathrm{a}, 5 \mathrm{a}}=3.0, J_{4 \mathrm{a}, 5^{\prime} \mathrm{a}}=5.4,4 \mathrm{a}-\mathrm{H}\right), 4.04\left(1 \mathrm{H}, \mathrm{ddd}, J_{4 \mathrm{~b}, 5 \mathrm{~b}}=\right.$ $\left.3.0, J_{4 \mathrm{~b}, 5^{\prime} \mathrm{b}}=6.0,4 \mathrm{~b}-\mathrm{H}\right), 3.99\left(1 \mathrm{H}, \mathrm{dd}, J_{3 \mathrm{a}, 4 \mathrm{a}}=6.0,3 \mathrm{a}-\mathrm{H}\right), 3.96(2 \mathrm{H}$, $\mathrm{m}, 2 \mathrm{c}-\mathrm{H}, 2 \mathrm{~b}-\mathrm{H}), 3.93\left(1 \mathrm{H}, \mathrm{ddd}, J_{3 \mathrm{c}, 4 \mathrm{c}}=3.6, J_{4 \mathrm{c}, 5 \mathrm{c}}=3.0, J_{4 \mathrm{c}, 5^{\prime} \mathrm{c}}=6.0\right.$, $4 \mathrm{c}-\mathrm{H}), 3.84\left(1 \mathrm{H}, \mathrm{dd}, J_{2 \mathrm{~b}, 3 \mathrm{~b}}=3.0, J_{3 \mathrm{~b}, 4 \mathrm{~b}}=6.0,3 \mathrm{~b}-\mathrm{H}\right), 3.78(1 \mathrm{H}, \mathrm{dd}$, $\left.J_{2 \mathrm{c}, 3 \mathrm{c}}=3.0, J_{3 \mathrm{c}, 4 \mathrm{c}}=6.0,3 \mathrm{c}-\mathrm{H}\right), 3.76\left(1 \mathrm{H}, \mathrm{dd}, J_{5 \mathrm{a}, 5^{\prime} \mathrm{a}}=11.8,5^{\prime} \mathrm{a}-\mathrm{H}\right)$, $3.67(2 \mathrm{H}, \mathrm{m}, 5 \mathrm{a}-\mathrm{H}, 5 \mathrm{c}-\mathrm{H}), 3.64\left(2 \mathrm{H}, \mathrm{m}, 5 \mathrm{~b}-\mathrm{H}, 5^{\prime} \mathrm{b}-\mathrm{H}\right), 3.54(1 \mathrm{H}$, $\left.\mathrm{dd}, J_{5 \mathrm{a}, 5 \mathrm{~b}}=12.6,5^{\prime} \mathrm{c}-\mathrm{H}\right) \mathrm{ppm} .{ }^{13} \mathrm{C} \mathrm{NMR}\left(125 \mathrm{MHz}, \mathrm{D}_{2} \mathrm{O}\right): \delta=$ $161.3\left(\mathrm{C}_{i p s o} \mathrm{C}_{6} \mathrm{H}_{4}\right), 142.3\left(\mathrm{C}_{p} \mathrm{C}_{6} \mathrm{H}_{4}\right), 126.1\left(\mathrm{C}_{m} \mathrm{C}_{6} \mathrm{H}_{4}\right), 116.2\left(\mathrm{C}_{o}\right.$ $\mathrm{C}_{6} \mathrm{H}_{4}$ ), 107.6 (1b-C), 107.4 (1c-C), 105.4 (1a-C), 83.9 (4c-C), 83.7 (4a-C), 82.4 (4b-C), 80.8 (2a-C, 2b-C, 2c-C), 76.5 (3a-C, 3b-C, 3cC), 66.7 (5a-C, 5b-C), 61.1 (5c-C) ppm. MS (ESI): $\mathrm{m} / \mathrm{z}$ calcd for $\mathrm{C}_{21} \mathrm{H}_{29} \mathrm{NNaO}_{15}[\mathrm{M}+\mathrm{Na}]^{+}$558.1435; found 558.2434.

$p$-Nitrophenyl $\alpha$-L-arabinofuranosyl-(1,5)-[ $\alpha$-L-arabinofuranosyl-(1,2)]- $\alpha$-L-arabinofuranoside (8). ${ }^{1} \mathrm{H}$ NMR (600 MHz, $\left.\mathrm{D}_{2} \mathrm{O}\right)$ : $\delta=8.11\left(2 \mathrm{H}, \mathrm{d}, J=9.6, \mathrm{H}_{m} \mathrm{C}_{6} \mathrm{H}_{4}\right), 7.08\left(2 \mathrm{H}, \mathrm{d}, J=9.6, \mathrm{H}_{o}\right.$ $\left.\mathrm{C}_{6} \mathrm{H}_{4}\right), 5.82\left(1 \mathrm{H}, \mathrm{d}, J_{1 \mathrm{a}, 2 \mathrm{a}}=1.2,1 \mathrm{a}-\mathrm{H}\right), 5.08\left(1 \mathrm{H}, \mathrm{d}, J_{1 \mathrm{c}, 2 \mathrm{c}}=1.2\right.$, $1 \mathrm{c}-\mathrm{H}), 4.91\left(1 \mathrm{H}, \mathrm{d}, J_{1 \mathrm{~b}, 2 \mathrm{~b}}=1.2,1 \mathrm{~b}-\mathrm{H}\right), 4.29\left(1 \mathrm{H}, \mathrm{dd}, J_{2 \mathrm{a}, 3 \mathrm{a}}=\right.$ $3.0,2 \mathrm{a}-\mathrm{H}), 4.15(2 \mathrm{H}, \mathrm{m}, 3 \mathrm{a}-\mathrm{H}, 4 \mathrm{a}-\mathrm{H}), 4.00\left(1 \mathrm{H}, \mathrm{dd}, J_{2 \mathrm{c}, 3 \mathrm{c}}=3.0\right.$, $2 \mathrm{c}-\mathrm{H}), 3.95\left(1 \mathrm{H}, \mathrm{dd}, J_{2 \mathrm{~b}, 3 \mathrm{~b}}=3.0,2 \mathrm{~b}-\mathrm{H}\right), 3.90\left(1 \mathrm{H}, \mathrm{ddd}, J_{3 \mathrm{c}, 4 \mathrm{c}}=3.6\right.$, $\left.J_{4 \mathrm{c}, 5 \mathrm{c}}=3.0, J_{4 \mathrm{c}, 5^{\prime} \mathrm{c}}=6.0,4 \mathrm{c}-\mathrm{H}\right), 3.88\left(1 \mathrm{H}, \mathrm{ddd}, J_{4 \mathrm{~b}, 5 \mathrm{~b}}=3.0, J_{4 \mathrm{~b}, 5^{\prime} \mathrm{b}}=\right.$ 6.0, 4b-H), $3.78(2 \mathrm{H}, \mathrm{m}, 3 \mathrm{~b}-\mathrm{H}, 3 \mathrm{c}-\mathrm{H}), 3.75\left(1 \mathrm{H}, \mathrm{dd}, J_{4 \mathrm{a}, 5 \mathrm{a}}=4.8\right.$, $\left.J_{5 \mathrm{a}, 5^{\prime} \mathrm{a}}=12.0,5 \mathrm{a}-\mathrm{H}\right), 3.66\left(2 \mathrm{H}, \mathrm{m}, 5 \mathrm{c}-\mathrm{H}, 5^{\prime} \mathrm{a}-\mathrm{H}\right), 3.54(2 \mathrm{H}, \mathrm{m}$, $\left.5 \mathrm{~b}-\mathrm{H}, 5^{\prime} \mathrm{c}-\mathrm{H}\right), 3.46\left(1 \mathrm{H}, \mathrm{dd}, J_{4 \mathrm{~b}, 5^{\prime} \mathrm{b}}=12.0, J_{5 \mathrm{~b}, 5^{\prime} \mathrm{b}}=12.0,5^{\prime} \mathrm{b}-\mathrm{H}\right) .{ }^{13} \mathrm{C}$ NMR (125 MHz, D $2 \mathrm{O}): \delta=161.3\left(\mathrm{C}_{i p s o} \mathrm{C}_{6} \mathrm{H}_{4}\right), 142.3\left(\mathrm{C}_{p} \mathrm{C}_{6} \mathrm{H}_{4}\right)$, $126.1\left(\mathrm{C}_{m} \mathrm{C}_{6} \mathrm{H}_{4}\right), 116.7\left(\mathrm{C}_{o} \mathrm{C}_{6} \mathrm{H}_{4}\right), 107.5$ (1c-C), 107.4 (1b-C), 104.4 (1a-C), 87.2 (2a-C), 84.1 (4b-C), 83.9 (4c-C), 82.5 (4a-C), 81.4 (2c-C), 81.0 (2b-C), 76.6 (3b-C), 76.5 (3c-C), 74.7 (3a-C), 66.0 (5a-C), 61.1 (5c-C), 61.0 (5b-C) ppm. MS (ESI): $\mathrm{m} / \mathrm{z}$ calcd for $\mathrm{C}_{21} \mathrm{H}_{29} \mathrm{NNaO}_{15}[\mathrm{M}+\mathrm{Na}]^{+}$558.1435; found 558.1612.

\footnotetext{
$\boldsymbol{p}$-Nitrophenyl $\boldsymbol{\beta}$-D-galactofuranosyl-(1,2)- $\boldsymbol{\beta}$-D-galactofuranoside (9). ${ }^{1} \mathrm{H}$ NMR $\left(600 \mathrm{MHz}, \mathrm{D}_{2} \mathrm{O}\right): \delta=8.10\left(2 \mathrm{H}, \mathrm{d}, J=9.0, \mathrm{H}_{m}\right.$ $\left.\mathrm{C}_{6} \mathrm{H}_{4}\right), 7.08\left(2 \mathrm{H}, \mathrm{d}, J=9.0, \mathrm{H}_{o} \mathrm{C}_{6} \mathrm{H}_{4}\right), 5.73\left(1 \mathrm{H}, \mathrm{d}, J_{1 \mathrm{a}, 2 \mathrm{a}}=1.8\right.$, $1 \mathrm{a}-\mathrm{H}), 5.06\left(1 \mathrm{H}, \mathrm{d}, J_{1 \mathrm{~b}, 2 \mathrm{~b}}=1.2,1 \mathrm{~b}-\mathrm{H}\right), 4.27\left(1 \mathrm{H}, \mathrm{dd}, J_{2 \mathrm{a}, 3 \mathrm{a}}=4.8\right.$, $2 \mathrm{a}-\mathrm{H}), 4.20\left(1 \mathrm{H}, \mathrm{dd}, J_{3 \mathrm{a}, 4 \mathrm{a}}=7.2,3 \mathrm{a}-\mathrm{H}\right), 3.99\left(1 \mathrm{H}, \mathrm{dd}, J_{2 \mathrm{~b}, 3 \mathrm{~b}}=3.6\right.$, $2 \mathrm{~b}-\mathrm{H}), 3.96\left(1 \mathrm{H}, \mathrm{dd}, J_{4 \mathrm{a}, 5 \mathrm{a}}=3.6,4 \mathrm{a}-\mathrm{H}\right), 3.93\left(1 \mathrm{H}, \mathrm{dd}, J_{3 \mathrm{~b}, 4 \mathrm{~b}}=6.2\right.$, $3 \mathrm{~b}-\mathrm{H}), 3.79\left(1 \mathrm{H}, \mathrm{dd}, J_{4 \mathrm{~b}, 5 \mathrm{~b}}=3.4,4 \mathrm{~b}-\mathrm{H}\right), 3.72\left(1 \mathrm{H}, \mathrm{ddd}, J_{5 \mathrm{a}, 6 \mathrm{a}}=7.4\right.$, $\left.J_{5 \mathrm{a}, 6^{\prime} \mathrm{a}}=5.0,5 \mathrm{a}-\mathrm{H}\right), 3.60\left(1 \mathrm{H}, \mathrm{ddd}, J_{5 \mathrm{~b}, 6^{\prime} \mathrm{b}}=7.8, J_{5 \mathrm{~b}, 6 \mathrm{~b}}=4.2,5 \mathrm{~b}-\mathrm{H}\right)$, $3.50\left(2 \mathrm{H}, \mathrm{m}, 6 \mathrm{a}-\mathrm{H}, 6^{\prime} \mathrm{a}-\mathrm{H}\right), 3.24\left(1 \mathrm{H}, \mathrm{dd}, J_{6 \mathrm{~b}, 6^{\prime} \mathrm{b}}=12.0,6 \mathrm{~b}-\mathrm{H}\right), 3.17$
}

$\left(1 \mathrm{H}, \mathrm{dd}, 6{ }^{\prime} \mathrm{b}-\mathrm{H}\right) \mathrm{ppm} .{ }^{13} \mathrm{C} \mathrm{NMR}\left(125 \mathrm{MHz}, \mathrm{D}_{2} \mathrm{O}\right): \delta=161.6\left(\mathrm{C}_{i p s o}\right.$ $\left.\mathrm{C}_{6} \mathrm{H}_{4}\right), 142.6\left(\mathrm{C}_{p} \mathrm{C}_{6} \mathrm{H}_{4}\right), 126.7\left(\mathrm{C}_{m} \mathrm{C}_{6} \mathrm{H}_{4}\right), 117.3\left(\mathrm{C}_{o} \mathrm{C}_{6} \mathrm{H}_{4}\right), 108.4$ (1b-C), 105.1 (1a-C), 88.5 (2a-C), 83.5 (4b-C), 83.2 (4a-C), 82.0 (2b-C), 77.2 (3b-C), 75.4 (3a-C), 70.9 (5b-C), 70.5 (5a-C), 63.3 (6b-C), 63.2 (6a-C) ppm. MS (ESI): $m / z$ calcd for $\mathrm{C}_{18} \mathrm{H}_{25} \mathrm{NNaO}_{13}$ $[\mathrm{M}+\mathrm{Na}]^{+}$486.1224; found 486.2127 .

\section{$\boldsymbol{p}$-Nitrophenyl $\boldsymbol{\beta}$-D-galactofuranosyl-(1,3)- $\boldsymbol{\beta}$-D-galactofuranoside} (10). ${ }^{1} \mathrm{H}$ NMR $\left(600 \mathrm{MHz}, \mathrm{D}_{2} \mathrm{O}\right): \delta=8.10\left(2 \mathrm{H}, \mathrm{d}, J=9.6, \mathrm{H}_{m}\right.$ $\left.\mathrm{C}_{6} \mathrm{H}_{4}\right), 7.08\left(2 \mathrm{H}, \mathrm{d}, J=9.6, \mathrm{H}_{o} \mathrm{C}_{6} \mathrm{H}_{4}\right), 5.69\left(1 \mathrm{H}, \mathrm{d}, J_{1 \mathrm{a}, 2 \mathrm{a}}=1.2\right.$, $1 \mathrm{a}-\mathrm{H}), 5.05\left(1 \mathrm{H}, \mathrm{d}, J_{1 \mathrm{~b}, 2 \mathrm{~b}}=1.8,1 \mathrm{~b}-\mathrm{H}\right), 4.41\left(1 \mathrm{H}, \mathrm{dd}, J_{2 \mathrm{a}, 3 \mathrm{a}}=3.0\right.$, $2 \mathrm{a}-\mathrm{H}), 4.14\left(1 \mathrm{H}, \mathrm{dd}, J_{3 \mathrm{a}, 4 \mathrm{a}}=6.0,3 \mathrm{a}-\mathrm{H}\right), 4.06\left(1 \mathrm{H}, \mathrm{dd}, J_{4 \mathrm{a}, 5 \mathrm{a}}=3.6\right.$, $4 \mathrm{a}-\mathrm{H}), 3.99\left(1 \mathrm{H}, \mathrm{dd}, J_{2 \mathrm{~b}, 3 \mathrm{~b}}=3.6,2 \mathrm{~b}-\mathrm{H}\right), 3.93\left(1 \mathrm{H}, \mathrm{dd}, J_{3 \mathrm{~b}, 4 \mathrm{~b}}=6.2\right.$, $3 \mathrm{~b}-\mathrm{H}), 3.80\left(1 \mathrm{H}, \mathrm{dd}, J_{4 \mathrm{~b}, 5 \mathrm{~b}}=4.2,4 \mathrm{~b}-\mathrm{H}\right), 3.79(1 \mathrm{H}, \mathrm{ddd}, 5 \mathrm{a}-\mathrm{H})$, $3.68\left(1 \mathrm{H}, \mathrm{ddd}, J_{5 \mathrm{~b}, 6^{\prime} \mathrm{b}}=7.8, J_{5 \mathrm{~b}, 6^{\prime} \mathrm{b}}=4.8,5 \mathrm{~b}-\mathrm{H}\right), 3.50(4 \mathrm{H}, \mathrm{m}, 6 \mathrm{a}-\mathrm{H}$, $\left.6^{\prime} \mathrm{a}-\mathrm{H}, 6 \mathrm{~b}-\mathrm{H}, 66^{\prime} \mathrm{b}-\mathrm{H}\right) \mathrm{ppm} .{ }^{13} \mathrm{C}$ NMR (125 MHz, $\left.\mathrm{D}_{2} \mathrm{O}\right): \delta=161.6$ $\left(\mathrm{C}_{i p s o} \mathrm{C}_{6} \mathrm{H}_{4}\right), 142.3\left(\mathrm{C}_{p} \mathrm{C}_{6} \mathrm{H}_{4}\right), 126.0\left(\mathrm{C}_{m} \mathrm{C}_{6} \mathrm{H}_{4}\right), 116.8\left(\mathrm{C}_{o} \mathrm{C}_{6} \mathrm{H}_{4}\right)$, 107.2 (1b-C), 105.6 (1a-C), 83.3 (4a-C), 82.9 (4b-C), 82.6 (3a-C), 81.3 (2b-C), 79.5 (2a-C), 76.6 (3b-C), 70.5 (5b-C), 70.4 (5a-C), 62.7 (6b-C, 6a-C) ppm. MS (ESI): $m / z$ calcd for $\mathrm{C}_{18} \mathrm{H}_{25} \mathrm{NNaO}_{13}[\mathrm{M}+$ $\mathrm{Na}]^{+}$486.1224; found 486.2245.

$\boldsymbol{p}$-Nitrophenyl $\boldsymbol{\beta}$-D-galactofuranosyl-(1,5)- $\boldsymbol{\beta}$-D-galactofuranoside (11). ${ }^{1} \mathrm{H}$ NMR $\left(600 \mathrm{MHz}, \mathrm{D}_{2} \mathrm{O}\right): \delta=8.10\left(2 \mathrm{H}, \mathrm{d}, J=9.0, \mathrm{H}_{m}\right.$ $\left.\mathrm{C}_{6} \mathrm{H}_{4}\right), 7.08\left(2 \mathrm{H}, \mathrm{d}, J=9.0, \mathrm{H}_{o} \mathrm{C}_{6} \mathrm{H}_{4}\right), 5.65\left(1 \mathrm{H}, \mathrm{d}, J_{1 \mathrm{a}, 2 \mathrm{a}}=1.8\right.$, $1 \mathrm{a}-\mathrm{H}), 5.06\left(1 \mathrm{H}, \mathrm{d}, J_{1 \mathrm{~b}, 2 \mathrm{~b}}=1.2,1 \mathrm{~b}-\mathrm{H}\right), 4.25\left(1 \mathrm{H}, \mathrm{dd}, J_{2 \mathrm{a}, 3 \mathrm{a}}=3.6\right.$, $2 \mathrm{a}-\mathrm{H}), 4.09\left(1 \mathrm{H}, \mathrm{dd}, J_{3 \mathrm{a}, 4 \mathrm{a}}=6.6,3 \mathrm{a}-\mathrm{H}\right), 4.03\left(1 \mathrm{H}, \mathrm{dd}, J_{4 \mathrm{a}, 5 \mathrm{a}}=\right.$ $3.6,4 \mathrm{a}-\mathrm{H}), 3.98\left(1 \mathrm{H}, \mathrm{dd}, J_{2 \mathrm{~b}, 3 \mathrm{~b}}=3.6,2 \mathrm{~b}-\mathrm{H}\right), 3.92(2 \mathrm{H}, \mathrm{m}, 3 \mathrm{~b}-\mathrm{H}$, $4 \mathrm{~b}-\mathrm{H}), 3.82\left(1 \mathrm{H}, \mathrm{ddd}, J_{5 \mathrm{a}, 6 \mathrm{a}}=7.4, J_{5 \mathrm{a}, 6_{\mathrm{a}}}=5.4,5 \mathrm{a}-\mathrm{H}\right), 3.68(1 \mathrm{H}$, ddd, $\left.J_{5 \mathrm{~b}, 6^{\prime} \mathrm{b}}=7.8, J_{5 \mathrm{~b}, 6 \mathrm{~b}}=4.2,5 \mathrm{~b}-\mathrm{H}\right), 3.60\left(2 \mathrm{H}, \mathrm{m}, 6 \mathrm{a}-\mathrm{H}, 6^{\prime} \mathrm{a}-\mathrm{H}\right)$, $3.56\left(1 \mathrm{H}, \mathrm{dd}, J_{6 \mathrm{~b}, 6^{\prime} \mathrm{b}}=12.0,6 \mathrm{~b}-\mathrm{H}\right), 3.50\left(1 \mathrm{H}, \mathrm{dd}, 6^{\prime} \mathrm{b}-\mathrm{H}\right) \mathrm{ppm} .{ }^{13} \mathrm{C}$ NMR (125 MHz, D $\left.\mathrm{D}_{2} \mathrm{O}\right): \delta=161.6\left(\mathrm{C}_{i p s o} \mathrm{C}_{6} \mathrm{H}_{4}\right), 142.3\left(\mathrm{C}_{p} \mathrm{C}_{6} \mathrm{H}_{4}\right)$, $126.0\left(\mathrm{C}_{m} \mathrm{C}_{6} \mathrm{H}_{4}\right), 116.8\left(\mathrm{C}_{o} \mathrm{C}_{6} \mathrm{H}_{4}\right), 107.0$ (1b-C), 105.2 (1a-C), 83.2 (4a-C), 82.7 (4b-C or 3b-C), 81.2 (2a-C, 2b-C), 76.5 (3a-C), 75.9 (3b-C or 4b-C), 75.1 (5a-C), 70.5 (5b-C), 62.7 (6b-C), 60.8 (6a-C) ppm. MS (ESI): $m / z$ calcd for $\mathrm{C}_{18} \mathrm{H}_{25} \mathrm{NNaO}_{13}[\mathrm{M}+\mathrm{Na}]^{+} 486.1224$; found 486.3852 .

$\boldsymbol{p}$-Nitrophenyl $\boldsymbol{\beta}$-D-galactofuranosyl-(1,6)- $\boldsymbol{\beta}$-D-galactofuranoside (12). ${ }^{1} \mathrm{H}$ NMR $\left(600 \mathrm{MHz}, \mathrm{D}_{2} \mathrm{O}\right): \delta=8.09\left(2 \mathrm{H}, \mathrm{d}, J=9.0, \mathrm{H}_{m}\right.$ $\left.\mathrm{C}_{6} \mathrm{H}_{4}\right), 7.07\left(2 \mathrm{H}, \mathrm{d}, J=9.0, \mathrm{H}_{o} \mathrm{C}_{6} \mathrm{H}_{4}\right), 5.66\left(1 \mathrm{H}, \mathrm{d}, J_{1 \mathrm{a}, 2 \mathrm{a}}=1.8\right.$, $1 \mathrm{a}-\mathrm{H}), 4.82\left(1 \mathrm{H}, \mathrm{d}, J_{1 \mathrm{~b}, 2 \mathrm{~b}}=1.8,1 \mathrm{~b}-\mathrm{H}\right), 4.25\left(1 \mathrm{H}, \mathrm{dd}, J_{2 \mathrm{a}, 3 \mathrm{a}}=3.6\right.$, $2 \mathrm{a}-\mathrm{H}), 4.06\left(1 \mathrm{H}, \mathrm{dd}, J_{3 \mathrm{a}, 4 \mathrm{a}}=6.0,3 \mathrm{a}-\mathrm{H}\right), 3.97\left(1 \mathrm{H}, \mathrm{dd}, J_{4 \mathrm{a}, 5 \mathrm{a}}=3.6\right.$, $4 \mathrm{a}-\mathrm{H}), 3.90\left(1 \mathrm{H}, \mathrm{dd}, J_{2 \mathrm{~b}, 3 \mathrm{~b}}=3.0,2 \mathrm{~b}-\mathrm{H}\right), 3.85(2 \mathrm{H}, \mathrm{m}, 3 \mathrm{~b}-\mathrm{H}, 5 \mathrm{a}-\mathrm{H})$, $3.71\left(1 \mathrm{H}, \mathrm{dd}, J_{4 \mathrm{~b}, 5 \mathrm{~b}}=4.8,4 \mathrm{~b}-\mathrm{H}\right), 3.66\left(1 \mathrm{H}, \mathrm{dd}, J_{6 \mathrm{a}, 6^{\prime} \mathrm{a}}=10.8, J_{5 \mathrm{a}, 6^{\prime} \mathrm{a}}=\right.$ $\left.4.2,6 \mathrm{a}^{\prime}-\mathrm{H}\right), 3.59\left(1 \mathrm{H}, \mathrm{ddd}, J_{5 \mathrm{~b}, 6^{\prime} \mathrm{b}}=7.2, J_{5 \mathrm{~b}, 6 \mathrm{~b}}=4.2,5 \mathrm{~b}-\mathrm{H}\right), 3.42$ $\left(3 \mathrm{H}, \mathrm{m}, 6 \mathrm{a}-\mathrm{H}, 6 \mathrm{~b}-\mathrm{H}, 66^{\prime} \mathrm{b}-\mathrm{H}\right) \mathrm{ppm} .{ }^{13} \mathrm{C}$ NMR (125 MHz, $\left.\mathrm{D}_{2} \mathrm{O}\right)$ : $\delta=161.4\left(\mathrm{C}_{\text {ipso }} \mathrm{C}_{6} \mathrm{H}_{4}\right), 142.2\left(\mathrm{C}_{p} \mathrm{C}_{6} \mathrm{H}_{4}\right), 126.1\left(\mathrm{C}_{m} \mathrm{C}_{6} \mathrm{H}_{4}\right), 116.7$ $\left(\mathrm{C}_{o} \mathrm{C}_{6} \mathrm{H}_{4}\right.$ ), 107.7 (1b-C), 105.3 (1a-C), 84.0 (4a-C), 83.0 (4b-C), 81.2 (2a-C), 81.0 (2b-C), 76.7 (3b-C), 76.5 (3a-C), 70.7 (5b-C), 68.9 (5a-C), 68.6 (6a-C), 62.7 (6b-C) ppm. MS (ESI): $\mathrm{m} / \mathrm{z}$ calcd for $\mathrm{C}_{18} \mathrm{H}_{25} \mathrm{NNaO}_{13}[\mathrm{M}+\mathrm{Na}]^{+}$486.1224; found 486.1533 .

$\boldsymbol{p}$-Nitrophenyl $\boldsymbol{\beta}$-D-galactofuranosyl-(1,2)- $\beta$-D-galactofuranosyl(1,2)- $\boldsymbol{\beta}$-D-galactofuranoside (13). ${ }^{1} \mathrm{H} \mathrm{NMR}\left(600 \mathrm{MHz}, \mathrm{D}_{2} \mathrm{O}\right): \delta=$ $8.12\left(2 \mathrm{H}, \mathrm{d}, J=9.0, \mathrm{H}_{m} \mathrm{C}_{6} \mathrm{H}_{4}\right), 7.10\left(2 \mathrm{H}, \mathrm{d}, J=9.0, \mathrm{H}_{o} \mathrm{C}_{6} \mathrm{H}_{4}\right)$, $5.74\left(1 \mathrm{H}, \mathrm{d}, J_{1 \mathrm{a}, 2 \mathrm{a}}=1.2,1 \mathrm{a}-\mathrm{H}\right), 5.16\left(1 \mathrm{H}, \mathrm{d}, J_{1 \mathrm{~b}, 2 \mathrm{~b}}=1.8,1 \mathrm{~b}-\mathrm{H}\right), 5.02$ $\left(1 \mathrm{H}, \mathrm{d}, J_{1 \mathrm{c}, 2 \mathrm{c}}=1.8,1 \mathrm{c}-\mathrm{H}\right), 4.27\left(1 \mathrm{H}, \mathrm{dd}, J_{2 \mathrm{a}, 3 \mathrm{a}}=2.4,2 \mathrm{a}-\mathrm{H}\right), 4.20$ $\left(1 \mathrm{H}, \mathrm{dd}, J_{3 \mathrm{a}, 4 \mathrm{a}}=6.0,3 \mathrm{a}-\mathrm{H}\right), 4.07\left(1 \mathrm{H}, \mathrm{dd}, J_{3 \mathrm{~b}, 4 \mathrm{~b}}=6.0,3 \mathrm{~b}-\mathrm{H}\right), 4.02$ $\left(1 \mathrm{H}, \mathrm{dd}, J_{2 \mathrm{~b}, 3 \mathrm{~b}}=3.6,2 \mathrm{~b}-\mathrm{H}\right), 3.97\left(1 \mathrm{H}, \mathrm{dd}, J_{2 \mathrm{c}, 3 \mathrm{c}}=3.6,2 \mathrm{c}-\mathrm{H}\right), 3.95$ $(2 \mathrm{H}, \mathrm{m}, 3 \mathrm{c}-\mathrm{H}, 4 \mathrm{a}-\mathrm{H}), 3.86\left(1 \mathrm{H}, \mathrm{dd}, J_{4 \mathrm{c}, 5 \mathrm{c}}=4.8,4 \mathrm{c}-\mathrm{H}\right), 3.80(1 \mathrm{H}$, 
$\left.\mathrm{dd}, J_{4 \mathrm{~b}, 5 \mathrm{~b}}=4.8,4 \mathrm{~b}-\mathrm{H}\right), 3.71(1 \mathrm{H}, \mathrm{ddd}, 5 \mathrm{a}-\mathrm{H}), 3.55(6 \mathrm{H}, \mathrm{m}, 5 \mathrm{~b}-\mathrm{H}$, $\left.5 \mathrm{c}-\mathrm{H}, 6 \mathrm{a}-\mathrm{H}, 6^{\prime} \mathrm{a}-\mathrm{H}, 6 \mathrm{~b}-\mathrm{H}, 6^{\prime} \mathrm{b}-\mathrm{H}\right) 3.22\left(1 \mathrm{H}, \mathrm{dd}, J_{6 \mathrm{c}, 6^{\prime} \mathrm{c}}=12.0,6 \mathrm{c}-\mathrm{H}\right)$, $3.18\left(1 \mathrm{H}, \mathrm{dd}, 6^{\prime} \mathrm{c}-\mathrm{H}\right) \mathrm{ppm} .{ }^{13} \mathrm{C}$ NMR $\left(125 \mathrm{MHz}, \mathrm{D}_{2} \mathrm{O}\right): \delta=161.4$ $\left(\mathrm{C}_{\text {ipso }} \mathrm{C}_{6} \mathrm{H}_{4}\right), 142.2\left(\mathrm{C}_{p} \mathrm{C}_{6} \mathrm{H}_{4}\right), 126.1\left(\mathrm{C}_{m} \mathrm{C}_{6} \mathrm{H}_{4}\right), 116.6\left(\mathrm{C}_{o} \mathrm{C}_{6} \mathrm{H}_{4}\right)$, 107.5 (1c-C), 106.7 (1b-C), 104.5 (1a-C), 88.1 (2a-C, 2b-C), 83.2 (4c-C), 82.5 (4a-C), 81.8 (4b-C), 81.3 (2c-C), 76.7 (3c-C), 75.2 (3bC), 74.7 (3a-C), 70.7 (5a-C), 70.0 (5b-C), 69.9 (5c-C), 62.7 (6a-C, 6b-C, 6c-C) ppm. MS (ESI): $m / z$ calcd for $\mathrm{C}_{24} \mathrm{H}_{35} \mathrm{NNaO}_{18}[\mathrm{M}+$ $\mathrm{Na}^{+}$648.1752; found 648.1912 .

$p$-Nitrophenyl $\beta$-D-galactofuranosyl-(1,2)- $\beta$-D-galactofuranosyl(1,3)- $\beta$-D-galactofuranoside (14). ${ }^{1} \mathrm{H} \mathrm{NMR}\left(600 \mathrm{MHz}, \mathrm{D}_{2} \mathrm{O}\right): \delta=$ $8.12\left(2 \mathrm{H}, \mathrm{d}, J=9.6, \mathrm{H}_{m} \mathrm{C}_{6} \mathrm{H}_{4}\right), 7.10\left(2 \mathrm{H}, \mathrm{d}, J=9.6, \mathrm{H}_{o} \mathrm{C}_{6} \mathrm{H}_{4}\right)$, $5.72\left(1 \mathrm{H}, \mathrm{d}, J_{1 \mathrm{a}, 2 \mathrm{a}}=1.8,1 \mathrm{a}-\mathrm{H}\right), 5.17\left(1 \mathrm{H}, \mathrm{d}, J_{1 \mathrm{~b}, 2 \mathrm{~b}}=1.8,1 \mathrm{~b}-\mathrm{H}\right)$, $5.01\left(1 \mathrm{H}, \mathrm{d}, J_{1 \mathrm{c}, 2 \mathrm{c}}=1.8,1 \mathrm{c}-\mathrm{H}\right), 4.44\left(1 \mathrm{H}, \mathrm{dd}, J_{2 \mathrm{a}, 3 \mathrm{a}}=2.4,2 \mathrm{a}-\mathrm{H}\right)$, $4.15\left(1 \mathrm{H}, \mathrm{dd}, J_{3 \mathrm{a}, 4 \mathrm{a}}=6.0,3 \mathrm{a}-\mathrm{H}\right), 4.08(3 \mathrm{H}, \mathrm{m}, 3 \mathrm{~b}-\mathrm{H}, 4 \mathrm{a}-\mathrm{H}, 4 \mathrm{~b}-\mathrm{H})$, $4.01\left(1 \mathrm{H}, \mathrm{dd}, J_{2 \mathrm{~b}, 3 \mathrm{~b}}=3.6,2 \mathrm{~b}-\mathrm{H}\right), 3.97\left(1 \mathrm{H}, \mathrm{dd}, J_{2 \mathrm{c}, 3 \mathrm{c}}=3.6,2 \mathrm{c}-\mathrm{H}\right)$, $3.93\left(1 \mathrm{H}, \mathrm{dd}, J_{3 \mathrm{c}, 4 \mathrm{c}}=6.0,3 \mathrm{c}-\mathrm{H}\right), 3.86\left(1 \mathrm{H}, \mathrm{dd}, J_{4 \mathrm{c}, 5 \mathrm{c}}=4.8,4 \mathrm{c}-\mathrm{H}\right)$, $3.80(2 \mathrm{H}, \mathrm{m}, 5 \mathrm{a}-\mathrm{H}, 5 \mathrm{~b}-\mathrm{H}), 3.71(2 \mathrm{H}, \mathrm{m}, 5 \mathrm{c}-\mathrm{H}, 6 \mathrm{a}-\mathrm{H}), 3.61(5 \mathrm{H}$, m, 6'a-H, 6b-H, 6'b-H, 6c-H, 6'c-H) ppm. ${ }^{13} \mathrm{C}$ NMR $(125 \mathrm{MHz}$, $\left.\mathrm{D}_{2} \mathrm{O}\right): \delta=161.4\left(\mathrm{C}_{i p s o} \mathrm{C}_{6} \mathrm{H}_{4}\right), 142.2\left(\mathrm{C}_{p} \mathrm{C}_{6} \mathrm{H}_{4}\right), 126.1\left(\mathrm{C}_{m} \mathrm{C}_{6} \mathrm{H}_{4}\right)$, $116.8\left(\mathrm{C}_{o} \mathrm{C}_{6} \mathrm{H}_{4}\right), 107.7$ (1c-C), 105.9 (1a-C), 105.7 (1b-C), 88.2 (2b-C), 83.6 (4a-C, 4b-C), 83.3 (4c-C), 82.5 (3a-C), 81.2 (2c-C), 79.4 (2a-C), 76.6 (3c-C), 75.4 (3b-C), 70.7 (5b-C), 70.6 (5c-C), 70.2 (5a-C), 62.8 (6a-C, 6b-C, 6c-C) ppm. MS (ESI): $\mathrm{m} / \mathrm{z}$ calcd for $\mathrm{C}_{24} \mathrm{H}_{35} \mathrm{NNaO}_{18}[\mathrm{M}+\mathrm{Na}]^{+}$648.1752; found 648.2551.

$p$-Nitrophenyl $\beta$-D-galactofuranosyl-(1,6)-[ $\beta$-D-galactofuranosyl$(1 \rightarrow 2)]-\beta$-D-galactofuranoside (15). ${ }^{1} \mathrm{H}$ NMR $\left(600 \mathrm{MHz}, \mathrm{D}_{2} \mathrm{O}\right)$ : $\delta=8.12\left(2 \mathrm{H}, \mathrm{d}, J=9.0, \mathrm{H}_{m} \mathrm{C}_{6} \mathrm{H}_{4}\right), 7.10\left(2 \mathrm{H}, \mathrm{d}, J=9.0, \mathrm{H}_{o} \mathrm{C}_{6} \mathrm{H}_{4}\right)$, $5.74\left(1 \mathrm{H}, \mathrm{d}, J_{1 \mathrm{a}, 2 \mathrm{a}}=1.8,1 \mathrm{a}-\mathrm{H}\right), 5.05\left(1 \mathrm{H}, \mathrm{d}, J_{1 \mathrm{c}, 2 \mathrm{c}}=1.8,1 \mathrm{c}-\mathrm{H}\right), 4.82$ $\left(1 \mathrm{H}, \mathrm{d}, J_{1 \mathrm{~b}, 2 \mathrm{~b}}=1.8,1 \mathrm{~b}-\mathrm{H}\right), 4.26\left(1 \mathrm{H}, \mathrm{dd}, J_{2 \mathrm{a}, 3 \mathrm{a}}=2.4,2 \mathrm{a}-\mathrm{H}\right), 4.20$ $\left(1 \mathrm{H}, \mathrm{dd}, J_{3 \mathrm{a}, 4 \mathrm{a}}=6.0,3 \mathrm{a}-\mathrm{H}\right), 3.98\left(1 \mathrm{H}, \mathrm{dd}, J_{2 \mathrm{c}, 3 \mathrm{c}}=3.6,2 \mathrm{c}-\mathrm{H}\right), 3.97$ $\left(1 \mathrm{H}, \mathrm{dd}, J_{4 \mathrm{a}, 5 \mathrm{a}}=3.6,4 \mathrm{a}-\mathrm{H}\right), 3.91\left(1 \mathrm{H}, \mathrm{dd}, J_{3 \mathrm{c}, 4 \mathrm{c}}=6.0,3 \mathrm{c}-\mathrm{H}\right), 3.89$ $\left(1 \mathrm{H}, \mathrm{dd}, J_{2 \mathrm{~b}, 3 \mathrm{~b}}=3.6,2 \mathrm{~b}-\mathrm{H}\right), 3.85(2 \mathrm{H}, \mathrm{m}, 3 \mathrm{~b}-\mathrm{H}, 5 \mathrm{a}-\mathrm{H}), 3.78(1 \mathrm{H}$, $\left.\mathrm{dd}, J_{4 \mathrm{c}, 5 \mathrm{c}}=4.8,4 \mathrm{c}-\mathrm{H}\right), 3.71\left(1 \mathrm{H}, \mathrm{dd}, J_{4 \mathrm{~b}, 5 \mathrm{~b}}=4.8,4 \mathrm{~b}-\mathrm{H}\right), 3.65(1 \mathrm{H}$, $\left.\mathrm{dd}, J_{6 \mathrm{a}, 6 \mathrm{a}}=10.2, J_{5 \mathrm{a}, 6 \mathrm{a}}=4.8,6 \mathrm{a}-\mathrm{H}\right), 3.60(2 \mathrm{H}, \mathrm{m}, 5 \mathrm{~b}-\mathrm{H}, 5 \mathrm{c}-\mathrm{H})$, 3.49 (1H, m, 6b-H), 3.45 (1H, m, 6'a-H), 3.39 (1H, m, 6’b-H), 3.19 $\left(1 \mathrm{H}, \mathrm{dd}, J_{6 \mathrm{c}, 6^{\prime} \mathrm{c}}=12.0, J_{5 \mathrm{c}, 6 \mathrm{c}}=4.2,6 \mathrm{c}-\mathrm{H}\right), 3.19\left(1 \mathrm{H}, \mathrm{dd}, J_{5 \mathrm{c}, 6^{\prime} \mathrm{c}}=7.8\right.$, 6 'c-H) ppm. ${ }^{13} \mathrm{C}$ NMR (125 MHz, $\left.\mathrm{D}_{2} \mathrm{O}\right): \delta=161.4\left(\mathrm{C}_{i p s o} \mathrm{C}_{6} \mathrm{H}_{4}\right)$, $142.2\left(\mathrm{C}_{p} \mathrm{C}_{6} \mathrm{H}_{4}\right), 126.1\left(\mathrm{C}_{m} \mathrm{C}_{6} \mathrm{H}_{4}\right), 116.6\left(\mathrm{C}_{o} \mathrm{C}_{6} \mathrm{H}_{4}\right), 107.9(1 \mathrm{c}-\mathrm{C})$, 107.6 (1b-C), 104.4 (1a-C), 88.1 (2a-C), 83.0 (4b-C), 82.9 (4c-C), 82.3 (4a-C), 81.4 (2c-C), 80.9 (2b-C), 76.7 (3b-C), 76.5 (3c-C), 74.7 (3a-C), 70.7 (5c-C), 70.2 (5b-C), 68.5 (6a-C), 68.4 (5a-C), 62.7 (6bC, 6c-C) ppm. MS (ESI): $m / z$ calcd for $\mathrm{C}_{24} \mathrm{H}_{35} \mathrm{NNaO}_{18}[\mathrm{M}+\mathrm{Na}]^{+}$ 648.1752 ; found 648.1688 .

\section{Immunostimulation assay}

Stock solutions of oligosaccharides were prepared in Iscove's Modified Dulbecco's medium (IMDM) (Gibco). LPS (E. coli 0127:B8, Sigma) was used as a positive control, negative controls had no oligosaccharide added. The murine macrophage cell line RAW264.7 (obtained from ATCC, USA) was maintained in IMDM supplemented with 10\% fetal bovine serum (FBS) (Gibco) at $37^{\circ} \mathrm{C}$ and $5 \% \mathrm{CO}_{2}$. Cells were harvested by centrifugation and resuspended in the same media to a final concentration of $5 \times$ $10^{5}$ cells $\mathrm{mL}^{-1}$. Thereafter, $5 \times 10^{4}$ RAW264.7 cells in $100 \mu \mathrm{L}$ of IMDM with $10 \%$ FBS per well were incubated with the indicated concentration of oligosaccharides at $37^{\circ} \mathrm{C}$ and $5 \% \mathrm{CO}_{2}$. After $18 \mathrm{~h}$, supernatants were collected and cytokine production was assessed by TNF- $\alpha$-specific ELISA (Mouse TNF- $\alpha$ ELISA Ready-SET-Go kit, eBioscience).

\section{Acknowledgements}

I.C. thanks the Czech Ministry of Education for a grant (MSM:6046137305). Financial support by the Ministère Français des Affaires Etrangères, the Programme Hubert Curien (Barrande), the Agence Nationale de la Recherche (JCJC06_ 140075) and the GDR-RDR2 "Aller vers une chimie écocompatible" are gratefully acknowledged, as well as Prof G. Davies for supplying the plasmid of Araf 51 .

\section{Notes and references}

1 P. Peltier, R. Euzen, R. Daniellou, C. Nugier-Chauvin and V. Ferrières, Carbohydr. Res., 2008, 343, 1897-1923.

2 P. J. Brennan, Tuberculosis, 2003, 83, 91-97.

3 F. Pan, M. Jackson, Y. Ma and M. McNeil, J. Bacteriol., 2001, 183, 3991-3998.

4 D. Chatterjee and K.-H. Khoo, Glycobiology, 1998, 8, 113-120.

5 C. E. Barry, Biochem. Pharmacol., 1997, 54, 1165-1172.

6 J. B. Houseknecht and T. L. Lowary, Curr. Opin. Chem. Biol., 2001, 5, 677-682.

7 P. Peltier, R. Daniellou, C. Nugier-Chauvin and V. Ferrières, Org. Lett., 2007, 9, 5227-5230.

8 G. Eppe, P. Peltier, R. Daniellou, C. Nugier-Chauvin, V. Ferrières and S. P. Vincent, Bioorg. Med. Chem. Lett., 2009, 19, 814-816.

9 P. Peltier, J.-P. Guégan, R. Daniellou, C. Nugier-Chauvin and V. Ferrières, Eur. J. Org. Chem., 2008, 5988-5994.

10 S. Notermans, G. H. Veeneman, C. W. E. M. Van Zuylen, P. Hoogerhout and J. H. Van Boom, Mol. Immunol., 1988, 25, 975-979.

11 E. A. Leitao, V. C. B. Bittencourt, R. M. T. Haido, A. P. Valente, J. Peter-Katalinic, M. Letzel, L. M. de Souza and E. Barreto-Bergter, Glycobiology, 2003, 13, 681-692.

12 M. L. Richards and T. L. Lowary, ChemBioChem, 2009, 10, 1920-1938.

13 Y. J. Lee, D. B. Fulse and K. S. Kim, Carbohydr. Res., 2008, 343, 1574 1584.

14 A. K. Pathak, V. Pathak, L. Seitz, J. A. Maddry, S. S. Gurcha, G. S. Besra, W. J. Suling and R. C. Reynolds, Bioorg. Med. Chem., 2001, 9, 3129-3143.

15 G. Zhang, M. Fu and J. Ning, Tetrahedron: Asymmetry, 2005, 16, 733738.

16 J. T. Smoot, P. Pornsuriyasak and A. V. Demchenko, Angew. Chem., Int. Ed., 2005, 44, 7123-7126.

17 Y. Bai and T. L. Lowary, J. Org. Chem., 2006, 71, 9672-9680.

18 M. Fu, G. Zhang and J. Ning, Carbohydr. Res., 2005, 340, 25-30.

19 L. Gandolfi-Donadio, C. Gallo-Rodriguez and R. M. de Lederkremer, Carbohydr. Res., 2008, 343, 1870-1875.

20 N. L. Rose, G. C. Completo, S. J. Lin, M. McNeil, M. M. Palcic and T. L. Lowary, J. Am. Chem. Soc., 2006, 128, 6721-6729.

21 C. Remond, R. Plantier-Royon, N. Aubry, E. Maes, C. Bliard and M. J. O'Donohue, Carbohydr. Res., 2004, 339, 2019-2025.

22 C. Remond, R. Plantier-Royon, N. Aubry and M. J. O'Donohue, Carbohydr. Res., 2005, 340, 637-644.

23 R. Euzen, G. Lopez, C. Nugier-Chauvin, V. Ferrières, D. Plusquellec, C. Rémond and M. O. Donohue, Eur. J. Org. Chem., 2005, 4860-4869.

24 G. Lopez, C. Nugier-Chauvin, C. Rémond and M. O’Donohue, Carbohydr. Res., 2007, 342, 2202-2211.

25 E. J. Taylor, N. L. Smith, J. P. Turkenburg, S. D’Souza, H. J. Gilbert and G. J. Davies, Biochem. J., 2006, 395, 31-37.

26 G. Paës, L. K. Skov, M. J. O’Donohue, C. Rémond, J. S. Kastrup, M. Gajhede and O. Mirza, Biochemistry, 2008, 47, 7441-7451.

27 M. Mayer and B. Meyer, Angew. Chem., Int. Ed., 1999, 38, 1784-1788.

28 S. Malá, H. Dvoráková, R. Hrabal and B. Králová, Carbohydr. Res., 1999, 322, 209-218.

29 M. Joe, D. Sun, H. Taha, G. C. Completo, J. E. Croudace, D. A. Lammas, G. S. Besra and T. L. Lowary, J. Am. Chem. Soc., 2006, 128, 5059-5072. 
30 A. Tzianabos, J. Y. Wang and D. L. Kasper, Carbohydr. Res., 2003, 338, 2531-2538.

31 F. Dourado, P. Madureira, V. Carvalho, R. Coelho, M. A. Coimbra, M. Vilanova, M. Mota and F. M. Gama, Carbohydr. Res., 2004, 339, $2555-2566$.

32 Q. Dong, J. Yao, J.-n. Fang and K. Ding, Carbohydr. Res., 2007, 342, $1343-1349$.

33 R. P. McGeary, C. Olive and I. Toth, J. Pept. Sci., 2003, 9, 405418.

34 D. Van Der Spoel, E. Lindahl, B. Hess, G. Groenhof, A. E. Mark and H. J. Berendsen, J. Comput. Chem., 2005, 26, 17011718.

35 V. Hornak and C. Simmerling, Proteins: Struct., Funct., Genet., 2003, 51, 577-590.

36 J. C. Gordon, J. B. Myers, T. Folta, V. Shoja, L. S. Heath and A. Onufriev, Nucleic Acids Res., 2005, 33, W368-371.

37 K. N. Kirschner, A. B. Yongye, S. M. Tschampel, J. González-Outeiriño, C. R. Daniels, B. L. Foley and R. J. Woods, J. Comput. Chem., 2008, 29, 622-655.

38 C. I. Bayly, P. Cieplak, W. Cornell and P. A. Kollman, J. Phys. Chem., 1993, 97, 10269-10280.
39 M. J. Frisch, G. W. Trucks, H. B. Schlegel, G. E. Scuseria, M. A. Robb, J. R. Cheeseman, J. J. A. Montgomery, T. Vreven, K. N. Kudin, J. C. Burant, J. M. Millam, S. S. Iyengar, J. Tomasi, V. Barone, B. Mennucci, M. Cossi, G. Scalmani, N. Rega, G. A. Petersson, H. Nakatsuji, M. Hada, M. Ehara, K. Toyota, R. Fukuda, J. Hasegawa, M. Ishida, T. Nakajima, Y. Honda, O. Kitao, H. Nakai, M. Klene, X. Li, J. E. Knox, H. P. Hratchian, J. B. Cross, V. Bakken, C. Adamo, J. Jaramillo, R. Gomperts, R. E. Stratmann, O. Yazyev, A. J. Austin, R. Cammi, C. Pomelli, J. W. Ochterski, P. Y. Ayala, K. Morokuma, G. A. Voth, P. Salvador, J. J. Dannenberg, V. G. Zakrzewski, S. Dapprich, A. D. Daniels, M. C. Strain, O. Farkas, D. K. Malick, A. D. Rabuck, K. Raghavachari, J. B. Foresman, J. V. Ortiz, Q. Cui, A. G. Baboul, S. Clifford, J. Cioslowski, B. B. Stefanov, G. Liu, A. Liashenko, P. Piskorz, I. Komaromi, R. L. Martin, D. J. Fox, T. Keith, M. A. Al-Laham, C. Y. Peng, A. Nanayakkara, M. Challacombe, P. M. W. Gill, B. Johnson, W. Chen, M. W. Wong, C. Gonzalez and J. A. Pople, Gaussian, Inc., Wallingford CT, 2004.

40 http://chemistry.csulb.edu/ffamber/tools.html.

41 H. J. C. Berendsen, J. P. M. Postma, W. van Gunsteren and J. Hermans, in In Intermolecular Forces, ed. B. Pullman, Reidel, Dordrecht, 1981, pp. 331-342. 